\title{
„Dva jsou víc než jeden“: Evaluace programu organizace Čmelák - Společnost přátel přírody
}

\author{
Lenka Broukalová, Václav Broukal, Jan Činčera \\ Envigogika 10 (2) - Recenzované články/ Reviewed Papers
}

Publikováno/Published dne 14. 3. 2015

DOI : $\underline{10.14712 / 18023061.468}$

\begin{abstract}
Článek prezentuje výsledky evaluace dlouhodobého programu organizace Čmelák Společnost prátel př́rody s názvem „Dva jsou víc než jeden". Program je primárně zaměřen na ověřování metod přispívajících k inkluzi ve vzdělávání a zahrnuje v sobě prvky osobnostně sociální výchovy, environmentální výchovy a řemesIných činností. Evaluace sestává ze dvou částí - evaluace "vývojového cyklu" a evaluace "tvořivě vzdělávacího cyklu". Evaluace vývojového cyklu využívá jednoduchý design vycházející z pozorování a polostrukturovaných rozhovorů s pedagogy spolupracujících škol a s lektory programů. Evaluace tvořivě vzdělávacího cyklu využívá smíšený design zahrnující dotazníkový průzkum - srovnání postojů žáků PŘED a PO programu a analýzu žákovských ohniskových skupin, pozorování a polostrukturované rozhovory s pedagogickými pracovníky a s lektory programu. Program přinesl výsledky $v$ rozvoji vztahů uvnitř jednotlivých zapojených tříd a částečně $\mathrm{i}$ $\checkmark$ navazování kontaktů a $v$ rozvoji spolupráce např́č třídami. Zároveň přinesl výsledky $\mathrm{i}$ $\checkmark$ tematických oblastech - environmentální a řemesIné. Evaluace také odhalila některé problematické aspekty programu.
\end{abstract}

\section{Klíčová slova}

Evaluace; smíšený design; ohnisková skupina; inkluze.

\begin{abstract}
This article presents the results of an evaluation of the long-term program implemented by organization Čmelák [English: Bumblebee] - Friends of Nature called 'Two are more than one'. The program is primarily focused on the validation of methods that contribute to inclusion in education and include elements of personal and social education, environmental education and trades. The evaluation consists of two parts - evaluation of the 'development cycle' and evaluation of the 'creative educational cycle'. The evaluation of the development cycle uses a simple design based on observation and semi-structured interviews with teachers from cooperating schools and with teachers of the programs. The evaluation of the creatively-educational cycle uses a mixed design incorporating a survey comparing the pupils' attitudes before and after the program, analysis of pupils' focus groups consisting, observations, and semi-structured interviews with teachers and programme teachers. The program provides results in the development of relations within individual classes, and partly also in establishing contacts and in the development of cooperation across
\end{abstract}


classes. The program also provides results in the thematic areas - environmental and trades. The evaluation also revealed some problematic aspects of the program.

\section{Keywords}

Evaluation; mixed design; focus group; inclusion. 


\section{1. Úvod}

Na následujících řádcích vám nabízíme zkušenosti z realizace a evaluace projektu, resp. programu „Dva jsou víc než jeden". Projekt byl zaměřen na problematiku inkluze, zejména na ověřování metod přispívajících $\mathrm{k}$ inkluzi ve vzdělávání prostřednictvím prvků osobnostně sociální výchovy, environmentální výchovy a řemesIných činností. Nejednalo se o typickou inkluzi na úrovni jedné školy či třídy, ale o vzájemné poznávání, navazování kontaktů a spolupráci napříč třídami běžných základních škol a praktických základních škol. Cílem evaluace bylo především zjistit, jak žáci hodnotí obsah programu i průběh spolupráce s žáky druhé třídy - v praxi tedy žáci běžných škol hodnotili spolupráci s žáky praktických základních škol a naopak. Dále bylo cílem evaluace zjistit, jak učitelé a lektoři v programu hodnotí proces inkluze.

Pro úplnost uvádíme, že název celého projektu i název programu (vzdělávací části projektu) byl stejný - „Dva jsou víc než jeden“. Pokud je v článku uveden termín program, mluví se o vzdělávací části projektu, v tom druhém případě je používán termín projekt.

\subsection{Podmínky pro inkluzivní vzdělávání v České republice}

Inkluzí ve vzdělávání rozumíme princip, jehož cílem je vytvoření takového systému, ve kterém existují podmínky pro vzdělávání všech žáků dohromady v hlavním vzdělávacím proudu, nevyskytují-li se podstatné důvody pro jiný postup. Speciální vzdělávací potřeby jsou pak pojímány jako součást společenské různorodosti. $V$ takovém vzdělávacím procesu jsou si všichni jeho účastníci vědomi, že každý z nás je v něčem odlišný, je individualitou a společně si vytváříme prostor pro život. Pojem inkluze někdy bývá zaměňován či ztotožňován s pojmem integrace, ale většina odborníků se kloní k odlišným definicím. Integrací pak rozumíme zapojování žákư se speciálními vzdělávacími potřebami do hlavních proudů vzdělávání a do běžných škol. Na rozdíl od integrace, kdy se pomůže jednotlivci v začlenění do třídy a přizpůsobení se třídě, znamená inkluze vytvoření diferencovaných podmínek různým dětem tak, že všechny, i když se mohou svými schopnostmi lišit, jsou uvedeny do prostředí, které je optimálně rozvíjí, a přitom mohou pracovat ve společné, výkonově heterogenní sociální skupině.

Mezi nejnaléhavější otázky současné inkluzivní pedagogiky patří samotný její koncept i způsob a tempo implementace do každodenní pedagogické praxe. Odborná i laická veřejnost je rozdělena $v$ názoru na integrační a inkluzivní snahy - jedna část spíše usiluje o začleňování žáků se speciálními vzdělávacími potřebami do běžných škol, resp. usiluje o vytváření podmínek potřebných pro vzdělávání různých dětí a druhá tento trend spíše zatracuje. Na obou stranách se zároveň vyskytují různá zjednodušení a zkreslení. Ukazuje se také, že existuje celá řada důvodů, které podporují takové rozdělení, např.:

- neustálené/rozdílné definice pojmů integrace, inkluze, ale i dalších souvisejících (rovnost, spravedlnost atd.),

- rozdělení školství na základní a speciální (i v rámci vzdělávání budoucích pedagogů),

- obavy o úroveň vzdělání,

- nejasnosti, jak pohlížet na děti z vyloučených komunit, kterých je v Čechách několik set,

- $\quad$ nedostatečná metodika v práci s rodiči apod.

V současné době existuje několik typů služeb, které mohou školám, resp. pedagogům, žákům i rodičům v inkluzivních snahách pomoci. Především se jedná o nabídku vzdělávání 
pedagogů a asistentů pedagogů například v nových metodách a přístupech v práci s tř́dou, ve vytváření a praktickém využití individuálních vzdělávacích plánů, ve formách komunikace $s$ dětmi. Dále existuje, i když ve velmi omezené míře, nabídka programů a workshopů pro jednotlivé třídy, zabývajících se napríklad tím, kdo je člověk s postižením, jak $s$ ním komunikovat a jak se $k$ němu chovat, jak mu pomoci při vytváření okruhu přátel. Opět $v$ omezené miře je $\mathrm{k}$ dispozici nabídka služeb pro rodiče $v$ podobě osobních konzultací, nabídka pomoci při tvorbě strategického plánu začlenění dítěte do běžné školy, pomoc v jednání se školou apod. Existuje i další podpora - oceňování škol, které usilují o inkluzivní přístup ve vzdělávání, pedagogicko-právní poradenství apod.

Zároveň je známa řada pojmenovaných potřeb, které doposud nejsou naplněny, ale podmiňují rozvoj kvalitního inkluzivního vzdělávání. Patří mezi ně např.:

- potřeba vzdělávání budoucích pedagogů v předmětné oblasti,

- včasná předškolní příprava,

- provázanost segmentu sociálního a vzdělávacího, např. zlepšení spolupráce školy a sociálních institucí,

- zlepšení poradenských služeb,

- posílení komunitního rozměru vzdělávání a rozvoj spolupráce s rodinami dětí,

- zajištění dostupnosti školní supervize, mentoringu v dané oblasti,

- zajištění dalšího vzdělávání pedagogických pracovníků přímo v jejich školách apod.

I přes uvedené nenaplněné potřeby pomalu přibývá škol, které se na proces inkluze zaměřují a posouvají se $v$ něm, snaží se spolupracovat na místní úrovni, otvírají se, přinášejí príklady dobré praxe.

\subsection{Př́lklad z praxe - alternativní přístup $\mathbf{k}$ inkluzi}

Dle vyjádření České odborné společnosti pro inkluzivní vzdělávání, o. s. je projekt realizovaný organizací Čmelák - Společnost přátel př́rody, který zde představujeme, unikátním př́kladem $v$ oblasti integrace a inkluze. Seznamování dětí z běžných základních škol s dětmi z praktických základních škol, které je jeho hlavním cílem, může přispívat $\mathrm{k}$ budoucí integraci a soudržnosti $v$ rámci komunity i společnosti. Výzkumy potvrzují, že pokud lidé zažívají pestrost a vnímají lidské odlišnosti již v dětství, potom je $v$ dospělosti lépe přijímají, a lépe též fungují ve vztazích a ve společnosti obecně.

V rámci programu "Dva jsou víc než jeden" se realizátoři snažili akceptovat individuální potřeby každého ze zúčastněných žáků, a to jak při prípravě pomůcek, tak $v$ prípadě potřeby podpory. Po domluvě s pedagogy byl zajištěn dostatečný počet asistentů. Prostředí, ve kterém se žáci pohybovali, bylo různorodé a rovnocenně přístupné všem. Cílem bylo naučit žáky přemýšlet o sobě, znát něco o prírodě, řemeslech, ale také umožnit jim poznávat se navzájem ve svých odlišnostech, které se mohou doplňovat, a vést je ke společnému podílení se na kultivaci prostředí, ve kterém spolu žijí. 


\section{Program „Dva jsou víc než jeden“}

Projekt realizovaný organizací Čmelák - Společnost přátel přírody probíhal od ledna 2013 do března 2015. Program „Dva jsou víc než jeden” byl určen pro děti z 3.-5. tříd běžných a praktických základních škol. Realizátoři projektem reagovali na problém, který viděli především $v$ tom, že děti se speciálními potřebami se vzdělávají odděleně od svých vrstevníků, kterým učení nedá tolik práce. Toto oddělení dle realizátorů přináší oběma skupinám řadu nevýhod - např́klad pocit méněcennosti těm, kteří chodí do praktické základní školy, předsudky a strach z odlišného těm, kteří chodí do běžné školy. V projektu se proto jeho realizátoři pokusili vytvořit prostor pro vzájemná setkávání, poznávání a spolupráci. Na následujících řádcích přiblížíme cíle a nastavení programu, kterého se vybrané kolektivy účastnily. Program probíhal $v$ různorodém prostředí, které bylo rovnocenně přístupné všem. Jednalo se o prostředí obou typů škol, jejich blízké okolí a další veřejně přístupná prostranství a místa (např. les, louka, turistická ubytovna, městské kulturní středisko, galerie apod.), dále se jednalo o soukromé dílny řemeslníků, chráněné dílny a zemědělská hospodářství.

Připomeňme jeden z hlavních cílů projektu - uplatňování a zlepšování metod a forem inkluzivního vzdělávání. Tento cíl byl naplňován vytvořením proinkluzivních žákovských týmů (vždy jedna třída běžné základní školy a jedna třída praktické základní školy), které se následně zapojily do připraveného vývojového, tvořivě vzdělávacího a precizačního cyklu programu „Dva jsou víc než jeden". A právě vývojový cyklus a tvořivě vzdělávací cyklus byly předmětem evaluace.

Dalším důležitým cílem projektu byl rozvoj metodické a didaktické pomoci při vzdělávání žáků se speciálními vzdělávacími potřebami a při jejich integraci do škol hlavního vzdělávacího proudu, a dále zvýšení kompetencí pracovníků škol a školských zařizení k inkluzivnímu vzdělávání. Pro naplnění těchto cílů byla vytvořena metodika programu a interaktivní pomůcky, a ty byly distribuovány do škol. Byla také realizována konference pro pedagogy zaměřená na metodickou podporu a zveřejněny př́klady dobré praxe v inkluzivním vzdělávání.

Dílčími cíli projektu byly rozvoj a uplatňování evaluačních metod a podpora výchovy $\mathrm{k}$ trvale udržitelnému životu.

\subsection{Vývojový cyklus}

Cíle vývojového cyklu, kterých chtěli realizátoři dosáhnout u žáků jako hlavní cílové skupiny projektu, byly následující (zde uvádíme pouze znění cílů, ale v rámci projektu byly dále rozpracovány do konkrétních výstupư a indikátorů):

Cíle v oblasti osobnostně sociální a v oblasti inkluze:

- Z Žáci rozumí hlavní motivační lince - pojmu „Dva jsou víc než jeden“.

- Žáci jsou motivovaní na setkání s druhou školou.

- Z Žáci spolu komunikují, spolupracují.

- Žáci vědí, že jsou každý jiný, a vnímají odlišnost pozitivně.

- Žáci se umí navzájem ohodnotit, dokážou ocenit přednosti jiných a respektují nedostatky. 
- Žáci jsou sebevědomí (dokážou ř́ci, $v$ čem jsou dobří, $v$ čem nejlepší a co opravdu skvěle umí).

- Žáci se ztotožňují se sadou pravidel pro setkání s dětmi z druhé školy.

Cíle v oblasti řemesIné (řemesIná linie):

- Žáci vhodně používají jednoduché nástroje a pracovní pomůcky.

- Žáci znají některé prírodní materiály a jejich zdroje.

- Žáci dokážou ocenit hodnotu ručního výrobku a dovednost "kumštýře”.

Cíle v oblasti environmentální (environmentální linie):

- Žáci znají základní ekologické souvislosti v různých typech prostředí (les, země, chov zviŕat).

- Žáci dokážou vyrobit funkční výrobek z přírodního materiálu.

- Žáci se cítí dobře v prírodě a v kontaktu s ní.

Vývojový cyklus byl realizován během druhého pololetí školního roku 2012/13 a sestával ze dvou běhů. Jeden žákovský tým (dvě partnerské školy - jedna třída běžné ZŠ a jedna třída praktické ZŠ) se účastnil běhu zahrnujícího především osobnostně sociální aktivity doplněné o environmentální výchovu. Druhý žákovský tým se účastnil běhu zahrnujícího především osobnostně sociální aktivity dopIněné o řemesIné činnosti. Každý z běhů (označovaný také jako environmentální linie a řemesIná linie) sestával z celkem 8 setkání, vždy po cca 14 dnech, trvajících přibližně 4 hodiny, z toho první, druhé a čtvrté setkání probíhalo $s$ každou třídou zvlášt', ostatní společně. Harmonogramy setkání jsou uvedeny v tabulkách číslo 1 a 2 .

\section{Vývojový cyklus - environmentální linie}

\begin{tabular}{|c|c|c|c|c|c|c|c|}
\hline \multicolumn{2}{|c|}{$\begin{array}{c}\text { Motivační } \\
\text { aktivity pro } \\
\text { žáky }\end{array}$} & $\begin{array}{c}\text { Stmelovací } \\
\text { aktivity pro } \\
\text { žáky }\end{array}$ & $\begin{array}{c}\text { Environmentálně- } \\
\text { kooperativní } \\
\text { program }\end{array}$ & $\begin{array}{c}\text { Environmentální } \\
\text { program (EVP) I. }\end{array}$ & $\begin{array}{c}\text { Environmentální } \\
\text { program (EVP) II. }\end{array}$ & $\begin{array}{c}\text { Environ- } \\
\text { mentální } \\
\text { workshop }\end{array}$ \\
\hline 1. & 2. & 3. & 4. & 5. & 6. & 7. & 8. \\
\hline $3 h$ & $3 h$ & $3 h$ & $3 h$ & $5 h$ & $4 h$ & $4 h$ & $5 h$ \\
\hline
\end{tabular}

Tabulka č. 1: Harmonogram setkání vývojového programu environmentální linie.

\section{Vývojový cyklus - řemesIná linie}

\begin{tabular}{|c|c|c|c|c|c|c|c|}
\hline \multicolumn{2}{|c|}{ Motivační aktivity pro žáky } & \multicolumn{2}{|c|}{ Stmelovací aktivity pro žáky } & Setkání s rodiči & Dílnička & Dílna & Vernisáž \\
\hline 1. & 2. & 3. & 4. & 5. & 6. & 7. & 8. \\
\hline $3 \mathrm{~h}$ & $3 \mathrm{~h}$ & $3 \mathrm{~h}$ & $3 \mathrm{~h}$ & $4 \mathrm{~h}$ & $4 \mathrm{~h}$ & $4 \mathrm{~h}$ & $4 \mathrm{~h}$ \\
\hline
\end{tabular}

Tabulka č. 2: Harmonogram setkání vývojového programu řemesIné linie.

$\checkmark$ úvodních setkáních obou běhů vývojového cyklu převládaly zejména programy zaměřené na stmelení kolektivu, spolupráci a seznámení obou partnerských tř́íd. Na prvním 
setkání si žáci vyrobili jmenovky a vytvořili vzkaz pro partnerskou třídu. Ten byl složen z fotografií exteriéru i interiérů jejich školy, tedy prostředí, které by žákům z partnerské tř́dy rádi představili. Dále si předali společné fotografie, kde u každého z žáků doplnili, co kdo má rád a v čem je dobrý. Zároveň partnerské tř́í̌ do vzkazu napsali i to, co rádi dělají společně a co by s partnerskou třídou rádi zažili. Na druhém setkání si přečetli vzkaz od partnerské třídy a zjistili, co mají společného. Zamysleli se nad tím, že každá hra pro svůj hladký průběh má určitá pravidla (např. fotbal), a uvědomili si, a jaká pravidla by měli dodržovat, aby jim spolu mohlo být dobře. Také si vytvořili deníky, které je pak provázely celým projektem - do nich si postupně ukládali jednotlivé pracovní listy. Třetí setkání bylo prvním společným; do jeho programu byly zařazeny seznamovací a rozehřívací hry, některé již $\mathrm{s}$ environmentálním či řemesIných podtextem. Čtvrté setkání proběhlo $v$ každé z partnerských tříd opět samostatně. Jednalo se o zpětnovazební setkání na první společné setkání.

Ve druhé části pak převažovaly programové aktivity zaměřené na environmentální, resp. řemeslnou výuku. Nezanedbatelnou součástí byla setkání s rodiči ( $v$ řemeslné linii mohli rodiče přjít na dílnu, v rámci které do školy poprvé přijeli také opravdoví řemesIníci, a dále na závěrečnou vernisáž; $v$ environmentální linii byli zváni na prírodní vernisáž $\mathrm{s}$ pečením buřtů).

Jednotlivá setkání probíhala vždy stř́́davě na jedné i druhé škole a žáci tak měli možnost poznávat i prostředí svých škol navzájem. Vývojový cyklus byl určitou testovací (experimentální) fází, jejiž výsledky sehrály významnou roli pro ladění rozsáhlejší programové části - tvořivě vzdělávacího cyklu.

\subsection{Tvořivě vzdělávací cyklus}

Cíle tvořivě vzdělávacího cyklu, kterých chtěli realizátoři dosáhnout u žáků jako hlavní cílové skupiny projektu, se shodovaly s cíli vývojového cyklu s tím rozdílem, že součástí tvořivě vzdělávacího cyklu (resp. každého realizovaného běhu) byly obě tematické linie (environmentální i řemesIná) a samozřejmě osobnostně sociální. Cíle tvořivě vzdělávacího cyklu byly navíc rozšířené o následující:

- Žáci přijímají jinakost jako součást vzdělávání i života.

- Žáci aktivně přispějí k zvelebení prostředí, ve kterém žijí, prací v týmu.

- Žáci aktivně přispějí k zvelebení obou škol prací v týmu.

- Žáci umí společně prezentovat své dílo.

Tvořivě vzdělávací cyklus probíhal celý školní rok 2013/14 a byl ve stejné podobě realizován ve třech bězích, tj. pro tři různé žákovské týmy (jeden tým tvořily dvě partnerské školy - jedna tř́ida běžné $Z S ̌$ a jedna třída praktické ZŠ). Pro úplnost uvádíme, že se jednalo o jiné žákovské týmy, než ve vývojovém cyklu. Každý tým $v$ rámci tvořivě vzdělávacího cyklu absolvoval celkem 12 setkání v rozmezí cca 3 týdnů, každé setkání o délce cca 4 hodiny, z toho první a druhé setkání probíhalo s každou třídou jednotlivých týmů zvlášt́ a ostatní společně (viz harmonogram $v$ tabulce číslo 3 a 4). Harmonogram setkání tvořivě vzdělávacího cyklu je uveden v tabulkách číslo 3 a 4. 
Tvořivě vzdělávací cyklus

\begin{tabular}{|c|c|c|c|c|c|c|}
\hline \multicolumn{4}{|c|}{ S chutí do toho } & Šikovné ruce & Za jeden provaz & Zvědavý školák \\
\hline $\begin{array}{c}\text { Motivační aktivity } \\
\text { pro žáky }\end{array}$ & $\begin{array}{c}\text { Stmelovací aktivity } \\
\text { pro žáky }\end{array}$ & Vánoční dílny & $\begin{array}{c}\text { Environmentální a } \\
\text { stmelovací aktivity }\end{array}$ & Exkurze \\
\hline 1. & 2. & 3. & 4. & 5. & 6. & 7. \\
\hline $4 \mathrm{~h}$ & $4 \mathrm{~h}$ & $4 \mathrm{~h}$ & $4 \mathrm{~h}$ & $4 \mathrm{~h}$ & $6 \mathrm{~h}$ & $5 \mathrm{~h}$ \\
\hline
\end{tabular}

Tabulka č. 3: Harmonogram setkání tvořivě vzdělávacího cyklu - první část.

\begin{tabular}{|c|c|c|c|c|}
\hline \multicolumn{2}{|c|}{ Dary prírody } & Co o tobě vím & Víme jak na to & Škola plná barev \\
\hline EVPI. & EVP II. & Dvoudenní pobyt & Tvořivá dílna & Vernisáž \\
\hline 8. & 9. & 10. & 11. & 12. \\
\hline $4 \mathrm{~h}$ & $4 \mathrm{~h}$ & 2 dny $(10 \mathrm{~h}+6 \mathrm{~h})$ & $5 \mathrm{~h}$ & $4 \mathrm{~h}$ \\
\hline
\end{tabular}

Tabulka č. 4: Harmonogram setkání tvořivě vzdělávacího cyklu - druhá část.

Jednotlivá setkání zahrnovala jak programy osobnostně sociální, tak i řemesIné a environmentální. Oproti vývojovému cyklu:

- Bylo vypuštěno původní 4. (zpětnovazební) setkání a nahrazeno setkáním s rodiči a řemesIníky.

- Do škol za žáky přijížděli řemeslníci, absolventi nejen běžných základních škol, ale i základních škol praktických.

- Přibyla návštěva autentických dílen řemesIníků.

- Přibyl i jeden dvoudenní společný pobyt spojený s návštěvou farmy.

- Závěrečné slavnostní vernisáže se nekonaly přímo v jedné z partnerských škol, ale na reprezentativních místech (společenský dům, městská galerie apod.); byly doprovázeny muzikou a zúčastnit se jich mohla i širší veřejnost.

- Žáci vyráběli nejen výrobky, které si odnášeli domů, ale postupně (z různých př́rodních materiálů) vyrobili i dva závěrečné obrazy krajiny, každé škole po závěrečné vernisáži pak zůstal jeden z obrazů na památku.

Celý tvořivě vzdělávací cyklus propojoval příběh - žáci byli plavčíky plavícími se na jedné lodi a v průběhu plavby je čekalo objevování neznámých ostrovů, na nichž zkoumali místní prírodu postupně jako tematické okruhy: les, země a louka. Poznávali zručné řemesIníky a také se sami učili šetrnému zpracovávání přírodních zdrojů, a to $v$ rámci tematických okruhů: dary lesa, dary země a dary zviřat. Každého z žáků celým projektem opět provázel deník (lodní deník v podobě kapsáře) a společná pravidla (lodní pravidla, která po předešlé domluvě byla zapsána na záchranný kruh a stvrzena znakem každého z žáků). Nově pak přibyla mapa plavby, na které byla označena jednotlivá setkání. Na začátku plavby byla mapa černobílá a po každém setkání se její odpovídající část proměnila v barevnou na konci plavby tedy byla celá mapa barevná. $V$ závěru pak byli všichni plavčíci pasováni na lodní kadety a dostali osvědčení o úspěšném absolvování plavby. 
Vývojového i tvořivě vzdělávacího cyklu se účastnily třídy, jejichž pedagogové projevili o účast zájem, nebo tř́dy, které byly osloveny realizátory projektu. Každá dvojice škol si byla geograficky velmi blízká, v některých případech šlo o školy ze stejného města.

\section{Metodika evaluace}

Evaluační plán (tj. evaluační otázky i metody evaluace) byl sestaven na základě seznámení se s projektem ze strany evaluátorů a na základě ujasnění si požadavků ze strany realizátora. Evaluace byla zaměřena především na sledování procesu inkluze - na vyhodnocení průběhu spolupráce mezi žáky tříd běžné a praktické základní školy, dále na vyhodnocení osobnostně sociálních aktivit, environmentálních aktivit a řemesIných činností jako prostředku inkluze, dále také na vyhodnocení formy, která byla pro realizaci programu zvolena. Předmětem sledování byla ale i spokojenost žáků a učitelů s programem. Cílem evaluace naopak nebylo zjištovat, zda program dosáhl všech cílů, které si vytýčil, bylo by to nad časové i finanční možnosti projektu. Ale při stanovování cílů evaluace se z cílů programu vycházelo. Metodika evaluace vývojového cyklu vycházela z kvalitativního př́stupu, evaluace tvořivě vzdělávacího cyklu kombinovala kvantitativní i kvalitativní přístup. Podrobnější popis metodiky následuje.

\subsection{Metodika evaluace vývojového cyklu}

Cílem evaluace v případě vývojového cyklu bylo odpovědět na následující otázky:

Jak žáci hodnotí obsah programu a jeho jednotlivé aktivity? Jak žáci hodnotí průběh spolupráce se žáky $z$ druhé skupiny? Jak učitelé hodnotí proces inkluze v programu? Jak lektoři hodnotí proces inkluze v programu?

Pro zodpovězení evaluačních otázek byl zvolen jednoduchý evaluační plán založený na pozorování a na polostrukturovaných rozhovorech s pedagogickými pracovníky spolupracujících škol a s lektory, kteří vedli jednotlivé programy.

Pozorování jako součást evaluace proběhlo na čtyřech vybraných dílčích akcích v rámci vývojového cyklu - environmentální linie a na čtyřech vybraných dílčích akcích vývojového cyklu - řemesIné linie, celkem čtyři pozorování v každé linii (pozorování na počátku akce proběhlo s každou skupinou zvlášt', další dvě pozorování proběhla, když skupina pracovala společně). Pozorování se týkalo zejména následujících oblastí: sdílení s kamarády, spontánní komunikace s žáky druhé tř́idy, spontánní spolupráce s žáky druhé třídy, aktivní zapojení do učení, propojování a přenášení nápadů a dovedností, reakce na nové informace a fakta, ztráta pozornosti, negativní reakce na žáky z druhé trí́dy apod.

Rozhovory $s$ učiteli měli hloubkovou povahu a byly polostrukturované. Probíhaly nejpozději do 1-2 týdnů po ukončení poslední realizované akce v rámci obou linií vývojového cyklu, osloveni byli celkem čtyři učitelé (zapojeny byly 4 tř́dy, 2 žákovské týmy). Rozhovor probíhal s každým učitelem zvlášt. Tyto rozhovory se dle plánu uskutečnily do konce června 2013. Rozhovor se dotýkal následujících oblastí: nejvýraznější momenty ze spolupráce, počátek spolupráce a očekávání, postoj k inkluzi, spojení tříd běžné Zš a praktické Zš, aktivity a jejich prínos pro inkluzi, celkové hodnocení.

Rozhovory s lektory měly také hloubkovou povahu a opět byly polostrukturované. Probíhaly nejpozději do 2-3 týdnů po ukončení poslední realizované akce $v$ rámci obou linií vývojového cyklu, a to celkem se třemi lektory. Rozhovor probíhal s každým lektorem zvlášt a dotýkal se následujících oblastí: nejvýraznější momenty ze spolupráce, počátek spolupráce 
a očekávání, postoj $k$ inkluzi, spojení tříd běžné Zš a praktické ZŠ, aktivity a jejich přínos pro inkluzi, spolupráce se školou, celkové hodnocení.

Organizace sběru dat obou linií vývojového cyklu byla následující: pozorování - duben až červen 2013, rozhovory se 4 učiteli - červen 2013, rozhovory s lektory - červen až červenec 2013, zpracování dat - květen až červenec 2013, zpráva z vyhodnocení obou vývojových programů - srpen 2013.

Analýza pozorování a rozhovorů vycházela z principu otevřeného kódování. Z jednotlivých zápisů z pozorování i z jednotlivých rozhovorů byly vybrány tzv. významové jednotky, tj. části textu nesoucí významnou informaci. Ty byly potom tzv. kódovány, tj. byly k nim přiřazovány kategorie na dvou hierarchických úrovních a dále byly interpretovány.

Celkem se podařilo získat data ze 4 pozorování a od 2 učitelů a 2 lektorů pro každou linii vývojového programu (řemesInou i environmentální). Po dokončení evaluace byla zpracována jedna souhrnná evaluační zpráva obsahující obě případové studie.

\subsection{Metodika evaluace tvořivě vzdělávacího cyklu}

Cílem evaluace $v$ případě tvořivě vzdělávacího cyklu bylo odpovědět na shodné evaluační otázky jako $v$ př́padě vývojového cyklu:

Jak žáci hodnotí průběh spolupráce $s$ žáky z druhé školy? Jak žáci hodnotí obsah programu a jeho jednotlivé aktivity? Jak učitelé hodnotí proces inkluze $v$ programu? Jak lektoři hodnotí proces inkluze v programu?

Pro zodpovězení evaluačních otázek byl ale vzhledem $\mathrm{k}$ většímu rozsahu tvořivě vzdělávacího cyklu zvolen složitější evaluační plán (smíšený design evaluace) založený na kvantitativní ćásti - zahrnoval dotazníkové šetření u žáků - a na kvalitativní části - zde bylo prováděno pozorování na programech, ohniskových skupinách s žáky, polostrukturované rozhovory s pedagogickými pracovníky spolupracujících škol a s lektory, kteří vedli jednotlivé programy. Výstupem evaluace tvořivě vzdělávacího cyklu byla zpráva zahrnující tři př́padové studie dle jednotlivých týmů, které se programu účastnily, dále vyhodnocení hlavních programových linií (osobnostně sociální, remesIné, environmentální) a zvolené formy či prostředků inkluze.

\section{Metody sběru dat kvantitativní části evaluace}

Pro kvantitativní část evaluace byl nejprve sestaven plán dotazníkového šetření a následně samotný dotazník. Dotazníkové šetření proběhlo u každého týmu vždy na začátku a na konci realizace celoročního tvořivě vzdělávacího cyklu. Žáci vyplňovali dvakrát v průběhu cca osmi měsíců stejný dotazník, skládající se z deseti položek využívající jednoduchou, "smajlíkovou" čtyřbodovou Likertovu škálu. Žáci vyhodnocovali, jak moc by se jim líbila určitá společná činnost s žákem z druhé školy. Pod pojmem „druhá škola“ byla pro žáky základní školy praktické představena třída z běžné základní školy, analogicky pro žáky běžné základní školy jimi byli žáci ze základní školy praktické. Při vyhodnocování byl nejvíce usměvavý "smajlík" indikující, že určitá společná činnost se žákem z druhé školy by se žákovi hodně líbila, kódován čtyřmi body, zatímco pokud by se mu líbila nejméně, tak jedním bodem. Celkem tedy žáci mohli získat 10-40 bodů, přičemž vyšší hodnoty byly interpretovány jako vyšší atraktivita spolupráce s žáky z druhé školy.

Reliabilita nástroje byla $v$ pretestu vyhodnocena na Cronbach alfa $=0,85$. Lze tedy ríct, že použitá škála je vysoce reliabilní a jednotlivé položky měří stejnou proměnnou. 
Z hodnocení byli následně vyřazeni respondenti, kteří nevyplnili jeden z testů. Celkově se ze tří běhů podařilo získat 67 respondentů. Protože tento počet je poměrně nízký, byly pro vyhodnocení použity neparametrické testy, resp. znaménkový test (a Wilcoxonův test pro ověření sporných výsledků) pro hodnocení rozdílů mezi testy před a po programu a ManWhitneyho test pro porovnání rozdílů mezi žáky základních a praktických škol. Hladina významnosti byla vždy alfa $=0,05$.

Je třeba upozornit, že malý počet respondentů zvyšuje riziko chyby druhého typu, tj. situace, kdy statistická analýza neprokáže existující rozdíl mezi skupinami. $\vee$ každém prípadě získané výsledky vypovídají pouze o programu „Dva jsou více než jeden“ a nelze je zobecňovat.

\section{Metody sběru dat kvalitativní části evaluace}

Pozorování jako součást evaluace proběhlo vždy $v$ rámci pobytového programu u každého zapojeného týmu. Pozorování se týkalo zejména následujících oblastí: sdílení s kamarády, spontánní komunikace s žáky druhé školy, spontánní spolupráce s žáky druhé školy, aktivní zapojení do učení, propojování a přenášení nápadů a dovedností, reakce na nové informace a fakta, ztráta pozornosti, negativní reakce na žáky z druhé školy apod.

Ohniskové skupiny s žáky měly hloubkovou povahu, vedle rozhovorů jde o jednu z hlavních metod kvalitativního výzkumu. Poskytují kvalitativní informace získané prostřednictvím otevřených otázek, principem této metody je řízená diskuse mezi 6-8 osobami. Ohniskové skupiny probíhaly vždy $v$ rámci pobytových programů, $v$ každém žákovském týmu zvlášt́ s třídou běžné ZŠ a zvlášt́ s třídou praktické ZŠ (celkem 6 tříd v rámci 3 týmů). Ohniskové skupiny se dotýkaly následujících oblastí: nejvýraznější momenty programu (co překvapilo, líbilo se, nelíbilo), spolupráce s druhou školou (jak moc se těšili, co překvapilo, líbilo se, nelíbilo), celkové hodnocení.

Rozhovory s učiteli měly hloubkovou povahu a byly polostrukturované. Probíhaly nejpozději do 1- 2 týdnů po ukončení poslední realizované akce v rámci tvořivě vzdělávacího cyklu. Rozhovor probíhal s každým učitelem zvlášt', celkem 3 učitelé běžné Zš a 3 učitelé praktické ZŠ. Tyto rozhovory se dle plánu uskutečnily do konce června 2014. Rozhovor se dotýkal následujících oblastí: nejvýraznější momenty ze spolupráce, počátek spolupráce a očekávání, postoj $\mathrm{k}$ inkluzi, spojení tříd běžné ZŠ a praktické ZŠ, posun ve vzájemném vnímání tř́́d běžné ZŠ a praktické ZŠ, jednotlivé aktivity a linie (osobnostně sociální, řemesIná, environmentální) a jejich prínos pro inkluzi, celkové hodnocení.

Rozhovory s lektory měly také hloubkovou povahu a opět byly polostrukturované. Probíhaly nejpozději do 2 týdnů po ukončení poslední realizované akce $v$ rámci tvořivě vzdělávacího cyklu. Rozhovor probíhal s každým lektorem zvlášt', celkem proběhl se třemi lektory. Tyto rozhovory se dotýkaly následujících oblastí: nejvýraznější momenty ze spolupráce, počátek spolupráce a očekávání, postoj k inkluzi, spojení tříd běžné Zš a praktické ZŠ, posun ve vzájemném vnímání trríd běžné ZŠ a praktické ZŠ, jednotlivé aktivity a linie (osobnostně sociální, řemesIná, environmentální) a jejich př́nos pro inkluzi, spolupráce se školou, celkové hodnocení.

Organizace sběru dat tvořivě vzdělávacího cyklu byla následující: dotazník pro žáky na začátku programu - říjen až listopad 2013; pozorování - květen 2014 v rámci pobytových akcí; ohniskové skupiny s žáky - květen 2014 v rámci pobytových akcí; dotazník pro žáky na konci programu - červen 2014; rozhovory se 6 učiteli - červen 2014; rozhovory se 3 lektory - červen 2014; zpráva z vyhodnocení tvořivě vzdělávacího cyklu - srpen 2014. 
Analýza pozorování, ohniskových skupin a rozhovorů vycházela opět z principu otevřeného kódování (jako u vývojových programů). Z jednotlivých zápisů z pozorování i z ohniskových skupin a jednotlivých rozhovorů byly vybrány tzv. významové jednotky, tj. části textu nesoucí významnou informaci. Ty byly potom tzv. kódovány, tj. byly $k$ nim přiřazovány kategorie na dvou hierarchických úrovních a dále byly interpretovány. Celkem byla získána data z 3 pozorování a od 6 učitelů a 3 lektorů. Po dokončení výzkumu byla zpracována jedna souhrnná evaluační zpráva zahrnující v rámci kvalitativní části výzkumu tři př́padové studie dle jednotlivých týmů, které se programu účastnily, dále obsahuje vyhodnocení hlavních programových linií (osobnostně sociální, řemesIné, environmentální) a zvolené formy jako prostředků inkluze.

\section{Zjištění}

\subsection{Zjištění - vývojový cyklus}

\section{Shrnutí:}

- Nejlépe hodnocenými aktivitami byla př́prava na vzájemné setkání tříd (vzkaz druhé tř́dě), v řemesIné linii pak den s řemesIníky (kovářem atd.), $v$ environmentální linii program věnující se různým typům prostředí - půda, les, louka.

- V řemesIné linii zůstaly třídy po celou dobu realizace projektu spíše oddělené, ale děti byly ochotné si vzájemně pomoci.

- V environmentální linii se děti většinou mezi sebou znaly, takže neměly problém s navázáním kontaktů. Konflikty vznikaly spíše na základě osobnostních specifik jednotlivců.

- Kritické okamžiky spolupráce byly následující - nechut' ke kontaktu s romskými dětmi, zapojování některých problematických dětí, fyzický kontakt $v$ prípadě některých dětí, opakovaná ztráta pozornosti.

- Celkový př́stup i hodnocení programu ze strany zapojených učitelek bylo ovlivněno několika vstupními faktory - tím, jak se ke spolupráci dostaly (zda z vlastního zájmu, či na základě povzbuzení někoho dalšího), jaká očekávání od programu měly a jaké postoje $\mathrm{k}$ inkluzi zaujímaly.

- Učitelky zapojené do vývojového cyklu více preferovaly tematické zaměření programů, inkluze stála až v pozadí jejich zájmu.

- Učitelky byly s programem spíše spokojené, pouze učitelka praktické školy očekávala více řemesel, s kterými se žáci nemají možnost jinak setkat a která si škola nemůže zajistit sama, určité výhrady měly učitelky k reflexivnímu bloku v rámci programu.

- Spojení tříd vnímaly učitelky spiše jako bezproblémové.

- Dle učitelky praktické základní školy zapojené v environmentální linii byly děti ze základní školy pro děti z praktické školy určitým vzorem, což umožnilo realizovat aktivity, které by pouze $v$ praktické $Z S ̌$ nebylo možné realizovat. 
- Lektoři považují za ideální poměr počtu žáků zapojených v programu $2: 1, z$ toho 2 = žáci běžné základní školy a 1 = žáci praktické školy při celkovém počtu maximálně 30 žáků na program.

- Lektoři považují environmentální a rukodělné činnosti za vhodný prostředek inkluze, protože nabízejí aktivity a činnosti, které dokážou oslovit obě skupiny dětí.

Následuje podrobný popis zjištění členěný dle evaluačních otázek.

\section{Žáci - hodnocení programu a průběh spolupráce s druhou třídou}

Zjištění týkající se toho, jak žáci vnímali program i spolupráci s druhou třídou, vycházela především z vyhodnocení interakcí, které mezi dětmi probíhaly, protože tam se podařilo získat největší objem dat (díky provedenému pozorování), a dále z rozhovorů $\mathrm{s}$ učiteli a lektory. Nebylo možné vycházet $z$ rozhovorů $s$ dětmi, nebot́ ty byly (oproti původnímu plánu) z evaluace vývojového cyklu kvưli časovým i finančním možnostem projektu vypuštěny.

Dle rozhovorů s lektory i učiteli byla v obou bězích vývojového cyklu (a v obou liniích - remesIné i environmentální) z osobnostně sociálních aktivit pro děti motivující príprava na vzájemné setkání tříd - vytváření vzkazu pro druhou skupinu (ještě před společným setkáním), kdy děti jednak $s$ nadšením připravovaly informace o sobě a svojí škole, zároveň se těšily na vzkaz od druhé skupiny. $V$ řemesIné linii potom jednoznačně jako nejzajímavější část programu vyšel den $s$ remeslníky (kovářem atd.). $V$ environmentální linii pak jako nejzajímavější je hodnocen environmentální program věnující se třem různým typům prostředí - půda, les, louka. Úspěch u některých dětí zaznamenaly také motivační písničky.

Naopak méně zajímavé byly $v$ řemesIné linii aktivity a činnosti, které byly pro děti známé (zejména na zapojené praktické škole se některé činnosti v programu podobaly tomu, co děti běžně dělají $v$ praktickém vyučování, a tedy nezískaly zájem účastníků). $\checkmark$ environmentální linii $z$ dostupných dat nešlo vyčíst, které aktivity byly méně zajímavé, dalo se pouze vysledovat, že při některých aktivitách se snižovala pozornost a soustredění dětí. To se později potvrdilo a více objasnilo $v$ rámci tvořivě vzdělávacího cyklu - aktivity, které vyžadovaly větší míru soustředění, strategického přemýšlení apod. se ukázaly jako náročné pro děti z praktické školy a snižovala se při nich jejich pozornost.

$\checkmark$ obou bězích vývojového cyklu spolu děti vzájemně dokázaly spolupracovat. $\checkmark$ řemesIné linii sice zůstaly třídy po celou dobu realizace projektu spiše oddělené, ale děti byly ochotné si vzájemně pomoci. Naopak specifikem skupiny $v$ environmentální linii bylo to, že se děti z významné části mezi sebou znaly (některé spolu chodily i první roky do stejné tř́́dy nebo byly $v$ príbuzenském vztahu apod.), tak nebyl takový problém $s$ navázáním kontaktů. Př́padné konflikty vznikaly spíše na základě osobnostních specifik jednotlivců. Asi nejvýraznějším konkrétním př́nosem $v$ rámci environmentální linie byly dle učitelky praktické školy pozitivní vzory, které představovaly děti ze základní školy pro děti z praktické školy. A tím mohly proběhnout aktivity, které by pouze s dětmi z praktické školy nebyly realizovatelné. Ani v jednom běhu vývojového cyklu však nelze prokázat, že došlo $\mathrm{k}$ posunu ve vzájemné pochopení dětí obou skupin.

Vysledovatelné byly i některé kritické okamžiky spolupráce $v$ obou liniích - nechut' ke kontaktu s romskými dětmi (např. u jedné dívky ze ZŠ v environmentální linii), zapojování některých problematických dětí (např. vietnamského chlapce také v environmentální linii), fyzický kontakt $v$ prípadě některých dětí, př́íp. opakovaná ztráta pozornosti. Všechny uvedené kritické okamžiky se později v rámci tvořivě vzdělávacího cyklu opět znovu objevily, ale lektoři byli připraveni s nimi pracovat. 


\section{Jak učitelé hodnotili proces inkluze v programu?}

Významnou roli $v$ hodnocení učitelů sehrálo několik vstupních faktorů - jak se jednotlivé učitelky ke spolupráci na projektu dostaly, jaká byla jejich očekávání i jak vnímaly problematiku inkluze.

Učitelka základní školy v řemesIné linii byla iniciátorkou, primárně sice projevovala zájem právě o řemeslné činnosti, ale více vnímala celkové nastavení programu a děti ze základní školy se zdály i celkově více motivované pro zapojení. Učitelka praktické základní školy nebyla iniciátorkou, do projektu vstoupila na základě oslovení učitelkou ze základní školy a zdá se, že hlavní motivací byla právě řemesla. Učitelky tříd zapojených $v$ environmentální linii již měly s organizací Čmelák zkušenosti z předcházejících projektů a obě měly celkem reálnou představu o tom, co bude probíhat.

Svoji roli sehrálo i to, jak učitelky vnímají problematiku inkluze. $V$ rámci řemesIné linie učitelka základní školy vnímala inkluzi už při zapojení do projektu jako běžnou součást fungování školy, kdežto učitelka praktické základní školy inkluzi z profesního hlediska výrazně odmítala, resp. ji považovala za ohrožení existence praktických škol. Projekt dokonce vnímala jako potvrzení toho, že inkluze v současných podmínkách není možná. $\checkmark$ rámci environmentální linie měla učitelka základní školy spíše rezervovaný přistup k inkluzi. Považovala ji za něco, co ve škole sama dělá, ale zároveň se jí zdálo, že otázka inkluze je hodně medializovaná, přitom je však vlastně nejasné zejména, co znamená inkluze sociálně znevýhodněných dětí, protože sociálně znevýhodněné děti se těžko identifikují, resp. objevují se jak v praktické, tak základní škole. Učitelka praktické školy vnímala inkluzi jako složitou otázku. $V$ podobě jednotné školy pro všechny ji odmítá jako nefunkční při současných podmínkách a možnostech. Avšak inkluzi v podobě, kterou nabízel projekt, vnímala jako smysluplnou.

Pro celkové závěry bylo velmi důležité i to, co učitelky od spolupráce očekávaly. $\checkmark$ rámci řemesIné linie ani základní škola, ani základní škola praktická nevstupovaly do projektu primárně kvůli inkluzi, ale především z důvodu tematického zaměření projektu (rukodělné činnosti - řemesla, př́p. praktické vyučování). Inkluze byla vnímána spíše jako vedlejší produkt projektu. Výrazný zájem o řemesla byl patrný zejména u praktické školy. $\mathrm{Na}$ druhou stranu ale učitelky obou škol podnikaly preventivní kroky k tomu, aby projekt fungoval i v oblasti inkluze (návštěva ZŠ na praktické ZŠ ještě před zahájením projektu). $\checkmark$ rámci environmentální linie základní škola nevstupovala do projektu primárně kvůli inkluzi, ale také především z důvodu tematického zaměření projektu (přírodověda, environmentální aktivity); inkluze byla vnímána spíše jako něco, co musí být. Očekávání učitelky praktické školy zahrnovala spíše interaktivní přístup a určitou formu práce. Z celého kontextu Ize vysledovat, že obě polohy programu pro ni byly důležité (inkluze i tematické zaměření).

Z těchto východisek pak vyplývalo celkové hodnocení aktivit, průběhu i př́nosů programu, včetně toho, jak fungovalo spojení tříd základní školy a praktické školy a jak učitelky vnímaly rukodělné činnosti a environmentální činnosti jako prostředek inkluze.

Učitelé velmi oceňovali velkou propracovanost programu - prvky osobnostně sociální výchovy, aktivní metody práce s dětmi, stejně tak připravenost environmentální linie a do značné míry i řemesIné.

$\checkmark$ rámci řemesIné linie učitelky hodnotily rukodělné činnosti $z$ pohledu potřeb své školy, již méně z pohledu prostředku inkluze. Výraznou spokojenost s rukodělnými činnostmi vykazovala základní škola, která nemá možnost více se praktickému vyučování věnovat, i když učitelka tuto oblast považuje za důležitou. Základní škola praktická více očekávala řemesla, s kterými se žáci nemají možnost jinak setkat a která si škola nemůže zajistit sama 
(z finančních, materiálních i jiných důvodů). Naopak praktické činnosti, kterých má škola $\checkmark$ rozvrhu sama o sobě hodně a které je tedy schopna si zajistit sama, príliš neoceňovala (ani jako prostředek inkluze). Učitelka základní školy formulovala, že za vhodný prostředek inkluze považuje mj. praktické činnosti a řemeslnou výrobu, dále aktivity, kde se mohou projevit všechny děti, i ty méně výrazné nebo zdatné. Toto vyjádření do určité míry koresponduje i s vyjádřením učitelky praktické základní školy, která za vhodné činnosti podporující inkluzi považuje mj. ty, kde si mohou být žáci vzájemně prospěšní (na něco jsou šikovnější žáci základní školy, na něco žáci praktické základní školy). Vyhodnocení ale ukazuje, že pro obě skupiny je dobré až nezbytné, aby šlo o aktivity, s kterými se běžně nesetkávají ve výuce, jsou pro ně nové, ale zároveň zvládnutelné.

$\checkmark$ rámci environmentální linie učitelka základní školy hodnotila environmentální činnosti z pohledu potřeb své školy, již méně z pohledu prostředku inkluze, avšak vyjadřovala s těmito činnostmi výraznou spokojenost, zejména z toho důvodu, že jí zapadaly do výuky, resp. do školního vzdělávacího programu. Setkání s tř́́dou z praktické školy vnímala spíše jako normální (děti se znaly, nějakou dobu dokonce některé byly ve stejném kolektivu). Učitelka praktické základní školy vnímala jako prostředek inkluze spíše formu hry (přirozené stmelování), aktivity, kde děti pracovaly ve smíšených skupinkách. Ale z hodnocení aktivit i z celkového kontextu vyplývá, že právě environmentální aktivity pro ni byly tou přirozenou formou hry, kde děti mohly uplatnit své praktické dovednosti a při tom vstupovat do nových vztahů.

$\checkmark$ rámci řemesIné linie učitelky vnímaly spojení obou skupin dětí spíše jako bezproblémové, nevyskytl se žádný výrazný pojmenovaný konflikt nebo negativní reakce, přesto jedna z učitelek vnímala program jako potvrzení svého rezervovaného až odmítavého přistupu k inkluzi. Lze $v$ programu pojmenovat momenty (interakce, aktivity, prínosy), které učitelky vnímaly pozitivně, př́p. je dokonce překvapily (např. vlídné přijetí žáků praktické školy třídou běžné základní školy, spontánní spolupráce). Učitelky ocenily aktivity zaměřené na rozvoj vzájemných kontaktů a vztahů. Avšak tento bezproblémový výsledek vzájemného fungování obou skupin přikládaly jak aktivitám probíhajícím v rámci programu, tak své vlastní aktivitě realizované ještě před zahájením projektu. Zároveň obě potvrzovaly, že obě třídy zůstaly po celou dobu projektu spíše oddělené.

$\checkmark$ rámci environmentální linie učitelky vnímaly spojení obou skupin dětí také celkově jako spíše bezproblémové, zejména díky tomu, že se děti ve velké míře již znaly, zde však byl pojmenován minimálně jeden konflikt týkající se odmítnutí spolupráce s romskými dětmi z praktické školy, který byl následně řešen lektory i učiteli. Další problémy vycházely spiše z osobností jednotlivých dětí, než ze spojení obou skupin (př́pad vietnamského chlapce se špatnou češtinou a další). Podařilo se pojmenovat momenty (interakce, aktivity, přínosy), které učitelky vnímaly pozitivně (např. děti ze základní školy zafungovaly jako pozitivní vzory pro děti z praktické školy). Učitelky ocenily aktivity zaměěené na rozvoj vzájemných kontaktů a vztahů (osobnostně sociální aktivity).

Lépe proces inkluze fungoval tam, kde pro učitele byl tento aspekt programu nějak (alespoň dílčím způsobem) významný, zřejmě to mělo vliv na celkovou motivaci dětí k setkávání se s druhou třídou, ale nebyl to jediný faktor ovlivňující průběh inkluze.

V obou liniích se objevily výhrady ke čtvrtému setkání, které probíhalo odděleně s jednotlivými tř́dami - reflexe dosavadních zkušeností dětí s programem. Učitelky vnímaly toto setkání jako náročné na pozornost i na myšlení dětí, což vyvolávalo zejména ve třídách praktických škol ztrátu pozornosti a nezájem. 


\section{Jak lektoři hodnotili proces inkluze $\mathbf{v}$ programu?}

Dle vyjádření lektorů (a potvrzovaly to i učitelky), třídy v rámci řemesIné linie zůstaly po celou dobu realizace projektu spiše oddělené, děti preferovaly své původní skupiny. Ale individuálně vznikala kamarádství, děti byly ochotné si vzájemně pomoci, zejména pokud to vyžadovala situace, a ke konci projektu i v př́padě, že byla možnost volného výběru. Lektoři ale dělali preventivní opatření a pracovali i s tím, jaké děti k sobě do spolupráce (ne)dávat.

Dle vyjádření lektorů (a opět to potvrzovaly i učitelky), specifikem skupiny zapojené $\checkmark$ environmentální linii bylo, že se děti z významné části mezi sebou znaly (některé spolu chodily i první roky do stejné tř́ídy nebo byly príbuzné apod.), takže nebyl takový problém $\mathrm{s}$ navázáním kontaktů. Problémy $v$ kontaktech/ve vztazích dle lektorů (a potvrzovaly to i učitelky) vyplývaly spíše z osobností některých jedinců, než ze setkání těch dvou skupin, byly však poměrně výrazné (negativní reakci jedné dívky na romské děti, pro dvě dívky ze základní školy bylo zvládnutelné zapojení do programu jen $v$ př́padě, že spolu byly ve skupince, zapojování vietnamského chlapce). Do řešení se úspěšně zapojovali jak lektoři, tak učitelé, a to ze základní školy i z praktické školy.

Lektoři se zabývali i problematikou počtu žáků účastnících se projektu, resp. poměrem mezi žáky běžné základní školy a praktické základní školy. Za ideální poměr považují $2: 1$, z toho 2 = žáci běžné základní školy a 1 = žáci praktické školy při celkovém počtu maximálně 30 žáků. Pokud byl tento poměr narušen, pak i spojení tř́id fungovalo hưře, většinou kladlo vyšší nároky na lektora, na jeho pozornost i další aspekty lektorské práce.

Lektoři vnímali, že $\mathrm{k}$ inkluzi přispívaly zejména aktivity, které byly přirozené. Za důležité považovali i skládání jednotlivých typů činností aktivit $v$ průběhu celého programu (cyklu). Na začátek byly zařazeny aktivity primárně zaměřené na sbližování, komunikaci atd., ale zároveň již byly proloženy aktivitami vztahujícími se $\mathrm{k}$ tematickému zaměěení programu. $V$ další fázi se uskutečňovaly více tematicky zaměřené činnosti proložené $v$ menší míře osobnostně sociálními, přičemž zájem se přesouval na předmětnou činnost (přirozenou, vzbuzující zájem, nadšení, vyžadující nenásilnou spolupráci). Vícekrát se ovšem v programu objevil aspekt ztráty pozornosti, většinou v př́padech, kdy byla aktivita pro děti dlouhá nebo př́liš náročná, prípadně $v$ závislosti na aktuální situací konkrétního žáka, ale také na celkovém přistupu učitele k programu.

Lektoři obecně považovali environmentální a rukodělné činnosti za vhodný prostředek inkluze, protože nabízejí aktivity a činnosti, které dokážou oslovit obě skupiny dětí z praktické i běžné školy - aktivity, které mohou vzájemnému kontaktu napomoci a které jsou zajímavé pro děti (nadchnou je a pohltí). Dle lektorů jako vhodný prostředek inkluze fungují zejména ty řemesIné činnosti, v rámci kterých je třeba si vzájemně pomáhat. Lektoři některé aktivity programu záměrně nastavili tak, aby děti byly nucené spolupracovat. Jako příklad úspěšných environmentálních aktivit lektoři uvádějí př́rodní pexeso nebo celodenní environmentální program o různých typech prostředí.

\subsection{Zjištění - tvořivě vzdělávací cyklus}

Zjištění, ke kterým se došlo v rámci evaluace tvořivě vzdělávacího cyklu, jsou členěna podle typu evaluace na kvantitativní a kvalitativní. $\vee$ rámci kvalitativní části jsou pak podrobně popsány tři běhy formou případových studií, dále tato část obsahuje vyhodnocení hlavních programových linií (osobnostně sociální, řemesIné, environmentální) a zvolené formy či prostředků inkluze. Zjištění tedy nejsou popsána formou odpovědí na evaluační otázky, ale dají se z uvedeného popisu odvodit. 


\section{Kvantitativní část evaluace Shrnutí:}

- Žáci z obou tříd každého týmu deklarovali na začátku programu (resp. při prvním dotazování, tj. po dvou oddělených a jednom společném setkání) zájem o spolupráci s žáky z druhé skupiny.

- Ve dvou ze tří týmů (tým A a tým C) zůstal tento zájem po programu srovnatelný, jako při prvním dotazování.

- $\quad V$ jednom týmu (tým $B$ ) došlo $k$ relativně značnému snížení zájmu o spolupráci. Ke snížení zájmu o spolupráci v daném týmu došlo u žáků ze základní školy, zatímco zájem u žáků z praktické školy zůstal po celou dobu srovnatelný.

\section{Zjištění podrobně:}

Tabulka č. 5 ukazuje rozdíly $v$ zájmu o spolupráci se žáky $z$ druhé školy pro všechny účastníky programu. Výsledky ukazují, že celkově se zájem o takovou spolupráci statisticky významně snižil. Naměřený záporný efekt je možné hodnotit jako středně silný.

\begin{tabular}{|c|c|c|c|c|c|}
\hline & Počet & Průměr & Odchylka & Z & P \\
\cline { 1 - 3 } PŘED & \multirow{2}{*}{67} & 34,4 & 5,3 & \multirow{2}{*}{2,49} & \multirow{2}{*}{0,01} \\
\cline { 1 - 1 } & & 30,4 & 8,5 & & \\
\hline
\end{tabular}

Tabulka č. 5: Zájem o spolupráci se žáky z druhé školy PŘED a PO programu pro všechny účastníky.

Výsledky také ukazují, že žáci uváděli před i po programu poměrně vysokou míru zájmu o takovou spolupráci (modus před i po $=40$ ).

Protože tvořivě vzdělávací cyklus probíhal $v$ několika bězích (a tedy $v$ různých týmech), mohla výsledky ovlivnit konkrétní implementace programu, ale i jiné faktory. Rozdíly $v$ zájmu o spolupráci PŘED programem a PO programu byly proto nyní vyhodnocovány rozděleně podle jednotlivých týmů. Statisticky významné snižení zájmu o spolupráci se tentokráte objevilo pouze u týmu B - viz tabulka č. 6.

\begin{tabular}{|c|c|c|c|c|c|}
\hline Tým A & Počet & Průměr & Odchylka & Z & $P$ \\
\hline PŘED & \multirow{2}{*}{23} & 33,7 & 5,1 & \multirow{2}{*}{0,2} & \multirow{2}{*}{0,8} \\
\hline $\mathrm{PO}$ & & 34 & 5 & & \\
\hline Tým B & Počet & Průměr & Odchylka & $z$ & $P$ \\
\hline PŘED & \multirow{2}{*}{23} & 33,2 & 6,4 & \multirow{2}{*}{2,7} & \multirow{2}{*}{0,005} \\
\hline PO & & 24,2 & 8,3 & & \\
\hline Tým C & Počet & Průměr & Odchylka & Z & $P$ \\
\hline PŘED & \multirow{2}{*}{21} & 36,5 & 3,2 & \multirow{2}{*}{0,7} & \multirow{2}{*}{0,4} \\
\hline $\mathrm{PO}$ & & 33,2 & 8,2 & & \\
\hline
\end{tabular}

Tabulka č. 6: Výsledky po jednotlivých týmech. 
Zjištěný negativní efekt u týmu B je možné hodnotit jako velký. Dílčí rozdíly u ostatních týmů nejsou statisticky významné.

Zájem o spolupráci mohl být dále ovlivněn typem školy. Tabulka č. 7 porovnává rozdíly PŘED programem a PO programu podle typů škol.

\begin{tabular}{|c|c|c|c|c|c|}
\hline Základní & Počet & Průměr & Odchylka & Z & P \\
\cline { 1 - 3 } PŘED & \multirow{2}{*}{41} & 33,8 & 5,1 & \multirow{2}{*}{2,9} & \multirow{2}{*}{0,003} \\
\cline { 1 - 3 } & & 29,3 & 7,2 & & \\
\hline PO & Počet & Průměr & Odchylka & Z & P \\
\cline { 1 - 4 } PŘED & \multirow{2}{*}{26} & 35,4 & 5,5 & \multirow{2}{*}{0} & \multirow{2}{*}{ * $^{*}$} \\
\cline { 1 - 3 } & & 32,1 & 10,1 & & \\
\hline
\end{tabular}

Tabulka č. 7: Výsledky podle typů škol. Poznámka: ${ }^{*}$ podle Wilcoxonova testu z $=1,1, p=$ 0,23 .

Výsledky ukazují, že zatímco zájem o spolupráci zůstal u žáků praktické školy statisticky stejný, u žáků ze základní školy se významně snížil. Žáci z obou typů škol deklarovali srovnatelný zájem o spolupráci před programem $(z=1,8, p=0,06)$, zatímco rozdíly mezi oběma skupinami po programu se významně lišily $(z=2,2, p=0,02)$.

\section{Kvalitativní část evaluace Shrnutí - tým A:}

- Došlo k naplnění očekávání ze strany lektorů, překonání očekávání u učitelů v oblasti zprostředkovaných zážitků a zkušeností, které byly nabídnuty dětem.

- Nejvíce ze všech týmů proběhlo sblížení obou tříd, na úrovni jednotlivců pravděpodobně vznikla nová kamarádství, navázané vztahy mezi některými žáky obou tříd přetrvaly i bezprostředně po skončení programu.

- Program měl pozitivní vliv na změnu v komunikaci mezi žáky běžné základní školy a jejich ochotu pomáhat druhým.

- Žáci praktické školy získali srovnání s dětmi z běžné školy a získali o nich lepší představu a mínění.

- $K$ procesu inkluze $v$ největší míre přispěly řemesIné aktivity, při kterých se nejvíce stíraly rozdíly mezi žáky praktické a běžné školy.

\section{Shrnutí - tým B:}

- Nepodařilo se ve větší míře zajistit propojení obou tříd.

- V průběhu programu došlo u žáků běžné základní školy k relativně značnému snížení zájmu o vzájemnou spolupráci s tř́́dou praktické školy.

- Program měl pozitivní vliv na větší propojení dětí uvnitř třídy běžné základní školy (nadané s méně nadanými dětmi). 
- Některé části programu z environmentální a osobnostně sociální linie byly vzhledem k schopnostem žáků praktické školy př́liš náročné (nároky na intelektové, strategické a komunikační dovednosti).

- K procesu inkluze $v$ největší míře přispěly řemesIné aktivity, při kterých se nejvíce stíraly rozdíly mezi žáky praktické a běžné školy.

\section{Shrnutí - tým C:}

- Podařilo se částečně odbourat počáteční nejistotu $z$ "jinakosti" žáků praktické školy v očích žáků základní školy.

- K významnému sblížení dětí napříč trrídami došlo jen $v$ několika jednotlivých prípadech.

- Pravidla uplatňovaná $v$ projektu měla pozitivní vliv na fungování tř́idy běžné ZŠ i mimo program.

- Žák běžné školy, který obtížně navazoval vztahy ve své třídě, dokázal navázat vztahy s žáky praktické školy.

- Některé části programu zejména z osobnostně sociální linie byly přiliš náročné z hlediska věku žáků.

- K procesu inkluze nejvíce přispívaly řemeslné aktivity a další aktivity, u kterých docházelo ke spontánní činnosti, a dále navštěvování se $v$ prostředí druhé školy. Naopak cíleně zaměřené aktivity z osobnostně sociální linie fungovaly výrazně méně.

\section{Shrnutí - jednotlivé programové linie, forma programu a motivační linka:}

- ŘemesIná linie měla největší vliv na proces inkluze ze všech tří linií. Při aktivitách linie se stíraly rozdíly mezi žáky základní a praktické školy. Řemeslná linie byla nejatraktivnější linií pro žáky i učitele. Ukázala možnosti pracovního uplatnění žákům praktické školy, zejména díky setkání s lidmi z chráněné dílny.

- K inkluzi nejvíce přispívaly ty aktivity z environmentální linie, které měly charakter pracovních a herních činností. Ostatní aktivity podporovaly inkluzi některými svými prvky. Celkově v environmentální linii dominovali žáci základní školy, žáci praktické školy byli upozaděni. Propracovanost a odbornost environmentální linie umožnila školám prostřednictvím programu významně naplňovat školní kurikulum v průřezovém tématu Environmentální výchova.

- Osobnostně sociální linie hrála důležitou roli při prvním kontaktu mezi oběma třídami. Měla vliv na zlepšení kolektivu některých tříd. Pro fungování dětí v jednotlivých třídách měla velký význam práce s pravidly, ta byla třídami využívána i po skončení programu. Spojování trríd pomocí těchto aktivit ale připadalo některým učitelům a žákům jako nepřirozené a některým žákům bylo nepř́jemné. Některé aktivity byly pro mladší žáky běžných a žáky praktických škol náročné vzhledem $k$ jejich věku a schopnostem.

- Zvolená forma programu (setkávání ve zhruba měsičních intervalech) po dobu jednoho roku se jeví většině učitelů jako ideální. Pouze paní učitelky v rámci týmu $\mathrm{A}$ by uvítaly kratší interval mezi jednotlivými setkáními (cca po čtrnácti dnech). 
- Problematicky fungovala motivační linka "společně dokážeme více než každý sám". Ukázalo se, že žáci praktické ZŠ byli pro žáky z běžné ZŠ spíše komplikací, protože společných výsledků se dosahovalo komplikovaněji a delší dobu, než kdyby pracovali žáci běžné ZŠ samostatně.

\section{Zjištění podrobně - tým A:}

Tým A se vyznačoval pozitivním naladěním a celkovou spokojeností jak žáků, tak učitelů. Žáci se od počátku na setkání $s$ druhou skupinou těšili, i když $s$ určitou mírou nejistoty danou zřejmě tím, že přesně nevěděli, co je při setkání s druhou třídou čeká. $\mathrm{Na}$ začátku se trochu otúkávali, ale s postupujícím časem Ize vysledovat pozitivní vývoj vztahů mezi žáky a navazování hlubších vztahů mezi jednotlivými třídami, které někteři žáci hodnotí jako nová kamarádství. $V$ počáteční seznamovací fázi pravděpodobně pozitivně zafungovaly hry na prvním společném setkání. Žáci z běžné ZŠ oceňovali nový náhled na žáky z praktické školy. Podle svědectví učitelů nově navázané vztahy přetrvávaly i bezprostředně po skončení projektu. Zejména u žáků základní školy došlo i k posunu ve vzájemných vztazích uvnitř vlastní třídy a $k$ posunu $v$ postojích $k$ druhým lidem obecně. Podle vyjádření učitelky $\checkmark$ porovnání $s$ paralelní tř́dou ve škole žáci, kteří prošli projektem, drží více pohromadě a mají větší ochotu pomáhat druhým, což se projevilo $v$ možnosti zapojit děti po skončení projektu do aktivit ve škole, které tuto spolupráci a ochotu pomáhat vyžadují. Ve třídě běžné základní školy měl projekt silný vliv na integrovaného žáka, který byl dle vyjádření učitelky po absolvování projektu výrazně komunikativnější. $K$ tomuto posunu mohlo dojít tím, že se zmíněný žák pravidelně setkával s dětmi s obdobnými potížemi a „problémy“, které dosud řešil sám. Žáci praktické školy byli trochu překvapeni, že jsou si v některých ohledech s žáky běžné školy podobní, což mohlo přispět $k$ odbourání některých předsudků. $V$ pozitivních vzájemných interakcích mezi žáky sehrál patrně nezanedbatelnou roli fakt, že žáci z obou tříd pocházeli z jednoho místa a již před začátkem projektu se někteří znali. Pozorovaná "pohoda" obou tříd mohla být dána také tím, jak v obou školách s žáky pracují a jaké výchovně vzdělávací př́stupy využívají, případně, jak děti na projekt připravili. Na to ale evaluací nemůžeme jednoznačně odpovědět, na tuto možnost Ize pouze usuzovat $z$ některých poznámek učitelů a pozorování chování dětí mimo oficiální program. $\mathrm{K}$ dobré atmosféře $v$ týmu zřejmě přispěl fakt, že děti s výraznými poruchami chování a extrémními osobnostními rysy $v$ týmu nebyly.

Program byl pro žáky týmu A zajímavý. Z realizovaných aktivit se jim nejvíce vybavili řemesIné činnosti a z celého programu je nejvíce ocenila i učitelka běžné ZŠ (i když ostatní části programu hodnotí jak děti, tak učitelka také poměrně vysoko). Důležité pravděpodobně bylo, že žáci vyráběli reálné výrobky a mohli si je odnést domů, což zvyšovalo smysluplnost těchto činností, a také to, že děti z běžné základní školy nemají oproti jiným činnostem ve škole tolik pracovní výchovy. Žáci z praktické školy si byli schopni vybavit více činností, které dělali $v$ rámci programu, než děti $z$ běžné základní školy, což může být dáno tím, že v průběhu školní výuky mohou mít oproti základní škole méně obdobných príležitostí zapojit se do projektů a dalších programů a více tedy projektem „žili" na rozdíl od dětí ze ZŠ, které mohou mít více podnětů a zážitky $z$ projektu tak přebíjet. $\vee$ reakcích žáků obou tříd se neobjevují výrazné negativní reakce na žádnou z částí programu - s programem byli spokojeni.

\section{Zjištění podrobně - tým B:}

Tým B a jeho fungování (pohled jedné třídy na druhou i vnímání jednotlivých aktivit) zřejmě výrazně ovlivnila charakteristika skupiny. Třídy praktické a běžné základní školy pocházely $z$ jiných měst a dopředu se neznaly. Rozdíly mezi třídami ještě umocňovala skutečnost, že někteří žáci z běžné základní školy byli výrazně nadaní a někteří žáci 
z praktické školy za nimi intelektově i dovednostně zaostávali. Mezi oběma třídami docházelo zřejmě opakovaně $k$ vzájemnému neporozumění, kdy žáci běžné základní školy nerozuměli chování žáků $z$ praktické školy (po několika neúspěšných pokusech žáků běžné ZŠ pomoci žákům $z$ praktické $Z S ̌ ~ v$ oblasti pravopisu, počtů, nebo $v$ rámci dalších složitějších forem spolupráce se začala většina žáků běžné ZŠ svým vrstevníkům z praktické ZŠ vzdalovat, nerozuměla jejich způsobu myšlení a chování). Díky tomu vznikla mezi částmi obou tříd bariéra, kterou se nepodařilo do konce projektu překonat. Spolupráci také výrazně ovlivnila přítomnost žáků se specifickými problémy a poruchami, které se projevovaly $v$ jejich chování, a to jak na straně žáků praktické, tak i na straně žáků běžné školy. Tyto faktory pravděpodobně ovlivnily ochotu obou skupin k vzájemnému sbližování a svou roli sehrály $\mathrm{i}$ $\checkmark$ konfliktech, které $v$ průběhu programu mezi žáky vznikaly (jak při programových činnostech, tak ve volném čase). $K$ největšímu sblí̌ení došlo mezi "slabšími" žáky třídy běžné ZŠ a některými žáky praktické ZŠ, u nichž nebyly takové rozdíly ve schopnostech a zájmech. Zejména u žáků praktické ZŠ byla snaha navazovat bližší vztahy s lektory, o které stáli více, než o vztahy s druhou třídou. Zde hrál zřejmě svou roli velmi vstřícný a přijímající postoj lektorů, který byl opakem odmítavého postoje dětí z běžné zš. Žáci z praktické školy byli spokojenější v těch částech programu, kdy byla každá třída samostatně.

Žáci obou tříd si byli schopni zpětně vybavit poměrně dost činností, kterými v průběhu celého programu prošli, což může ukazovat na určité zaujetí programem. $Z$ toho, co žáci zmiňovali, nejvíce vystupovaly činnosti řemeslné, ale u tohoto týmu hojně i další činnosti z environmentální a osobnostně sociální linie (pamatovali si je především žáci z běžné ZŠ). Obě třídy se nejvíce sbližovaly při remeslných aktivitách, kdy se stíraly rozdíly ve

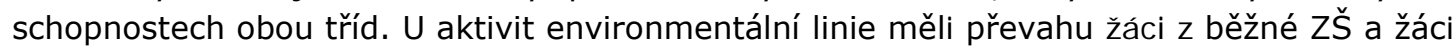
z praktické školy byli spíše pozorovatelé. Zde není možné jednoznačně říci, zda byly aktivity pro žáky dané třídy př́liš náročné, anebo zda žáci běžné Zš byli výrazně zdatnější a žáky $z$ praktické školy zastínili. $V$ kontextu toho, co bylo řečeno $v$ předchozím odstavci, měli žáci nechut' $\mathrm{k}$ aktivitám, u kterých docházelo $\mathrm{k}$ fyzickému kontaktu mezi žáky praktické a běžné ZŠ, což mohlo mít vliv i na očekávané vyznění některých osobnostně sociálních aktivit, jejichž záměrem bylo vzájemné sblížení obou tříd (místo očekávaného efektu mohl nastat efekt opačný). Nad rámec možností některých žáků z praktické školy byly prípravné a reflektivní části programů, kdy se po delší dobu sedělo a povídalo v kroužku a oni se museli soustředit. Tím byl efekt těchto činností pravděpodobně oslaben. Pro některé žáky praktické školy byl z hlediska jejich schopností rovněž problém se plnohodnotně zapojit do aktivit, při kterých bylo nutné strategicky přemýšlet a domlouvat se, čímž se rovněž zřejmě sniźil i zamýšlený efekt těchto činností na tyto žáky.

Přestože spolupráce obou tříd byla $v$ mnohém problematická, přinesla dle učitelky běžné základní školy efekt do proměny vztahů uvnitř třídy - nadanější žáci třídy začali více akceptovat ty méně nadané. Pro žáky $z$ praktické školy měl zřejmě větší význam program samotný a pozitivní príjetí od lektorů programu.

\section{Zjištění podrobně - tým C:}

Fungování týmu $C$ rovněž výrazně ovlivnila charakteristika skupiny, tentokrát věkové složení obou tříd. Tým $C$ tvořili mladší žáci (1.-3. třídy u běžné základní školy a 3. třídy u praktické základní školy). Oproti ostatním týmům mladší věk žáků způsobil některé odlišnosti. Žáci týmu C pravděpodobně více prožívali dobrodružnou linku v programu (více si vybavovali aktivity s tajemnou truhlou apod.) a více preferovali herní aktivity. Oproti tomu měli problém $s$ aktivitami, které kladly nároky na kooperaci a vyžadovaly větší míru trpělivosti. Pravděpodobně nebyli pro tyto aktivity $z$ vývojového hlediska zralí. Problém $u$ těchto dětí nastával $\mathrm{i} v$ př́padě potřeby překonávat určité nepohodlí (např. chlad, únavu apod.), což zřejmě opět souvisí s nízkým věkem žáků a také s malou navyklostí této skupiny 
na prírodní prostředí. Některé části programu (soudě dle výpovědí paní učitelky) byly pro děti př́liš náročné (týkalo se zejména některých činností osobnostně sociálních) a byly vhodnější pro starší věkovou skupinu. Při zadávání a reflexi některých aktivit a při vyhodnocování obecně nastával problém s udržením pozornosti.

Obě tř́́dy obdobně jako u týmu B pocházely z různých míst. Žáci ze ZŠ byli na počátku trochu zaskočeni vzhledem (zejména barvou pleti či vlasů) žáků z praktické školy, což pravděpodobně pramení $z$ určité izolovanosti jejich školy. První kontakt mezi žáky obou tříd byl ostýchavý, ale postupně docházelo $\mathrm{k}$ promíchávání obou skupin. $\mathrm{V}$ tomto týmu $\mathrm{C}$ jako jediném byl zaznamenán spontánní zájem o fyzický kontakt mezi některými dětmi napříč třídami. Toto rovněž $s$ největší pravděpodobností souvisí s nízkým věkem dětí a jejich přirozenou spontaneitou. Bližší vztahy mezi dětmi vznikaly jen u některých jednotlivců, $z$ hlediska celku došlo pouze $k$ mírnému posunu. Žáci obou tříd si vytvářeli vazby na jednotlivé lektory a pravděpodobně se těšili především na setkání s nimi, setkání s druhou tř́ídou bylo až druhořadé. Určitou roli zde mohl sehrát rovnocenný a partnerský př́stup lektorů k oběma třídám, který zaznamenaly i učitelky. Ke sbližování dětí obou tříd docházelo zejména při přirozených činnostech - při práci ( $v$ rámci řemesIné linie), při některých činnostech mimo hlavní programovou linii (např. společná př́prava svačiny). $v$ tomto týmu hrálo velkou roli také stř́dání škol a potřeba dětí představit druhé tř́dě své prostředí. Pravděpodobně méně fungovaly cílené osobnostně sociální aktivity (viz výše). Vše zmíněné opět s největší pravděpodobností souvisí s věkem dětí. Program byl významný pro jednoho žáka z běžné základní školy, který měl problém začlenit se do třídního kolektivu. $V$ průběhu projektu se mu podařilo navázat vztahy s žáky z praktické školy.

Třídě běžné základní školy pomohla pravidla nastavená v rámci projektu. Ta měla vliv na změnu fungování žáků, což mělo dopady i mimo program. Pro obě třídy byla zajímavá řemesIná linka, žáci základní školy deklarovali, že si z programu odnesli i znalosti, které využijí ve škole (např. v prvouce), obdobně i obě učitelky viděly pro své třídy význam $\checkmark$ environmentální linii, která jim výrazně pomohla při naplňování prưřezového tématu environmentální výchova. Učitelka z praktické školy soudila, že program byl významný pro jejich tř́́du tím, že v praxi viděli, jak může vypadat jejich budoucí profese.

\section{Zjištění podrobně - řemesIná linie:}

ŘemesIná linie a její aktivity nejvíce z celého programu podporovaly proces inkluze. Učitelé i lektoři se shodli na tom, že při rukodělných činnostech se nejvíce stíraly rozdíly mezi žáky z obou škol, což mohlo být důsledkem zájmu žáků běžné zŠ o tyto činnosti (jako důsledek nízké časové dotace atraktivních pracovních činností na ZŠ) a zároveň zaměřením praktických škol na tuto činnost. Tyto činnosti většinou nevyžadovaly od žáků praktických ZŠ výrazné využití rozumových schopností. Komunikace a spolupráce mezi žáky probíhala spontánně a nenuceně.

ŘemesIné aktivity byly velmi atraktivní pro žáky, kteří sami oceňovali možnost vytvořit si smysluplný, praktický a hezký výrobek, odnést si jej domů a pochlubit se jím, což pravděpodobně zvýšilo jejich sebedůvěru $v$ těchto činnostech. Žákům praktické školy mohl dle slov paní učitelky program ukázat možnosti jejich uplatnění v praktickém životě. Velký význam v programu mělo zapojení nejen běžných řemesIníků do projektu, ale rovným dílem také zručných řemesIníků sociálně-terapeutických dílen pro osoby s mentálním postižením (chráněných dílen), což pozitivně hodnotili učitelé, lektoři i žáci. Ti měli možnost vidět, jak se uplatňují lidé s různými omezeními. 
Žáci si z řemesIné linie po skončení programu opakovaně vzpomínali zejména na setkání se včelařem, truhlářem a sklářem a na práci se včelím voskem, dále na brašnárnu, kováře, práci s keramikou a výrobu kapsářů.

Součástí programu bylo i tvoření $s$ rodiči, které bylo hodnoceno pozitivně z hlediska motivace žáků zde se ale zároveň projevil menší zájem rodičů dětí z praktických škol o toto setkání.

\section{Zjištění podrobně - environmentální linie:}

Environmentální linie přispívala dle lektorů a učitelů k inkluzi částečně. I tato linie obsahovala aktivity, které měly charakter pracovních činností (např. vyřezávání náletových dřevin a úklid $v$ lese). Tyto aktivity pravděpodobně $k$ inkluzi přispívaly nejvíce $z$ obdobných důvodů jako u linie řemesIné. Ostatní aktivity podporovaly inkluzi některými svými prvky (zprostředkovaní zážitku, společné hry, skupinová práce). Při environmentálních aktivitách byla vůdčí role na žácích z běžné základní školy a žáci z praktické školy byli upozaděni.

Školy si prostřednictvím programu částečně naplňovaly průřezové téma environmentální výchova svých školních vzdělávacích programů. Deklarovali, že prínosem pro ně byla propracovanost a odborná stránka programu.

Žáci si z environmentálních aktivit opakovaně vybavili činnosti spojené s prací (práce v lese, sázení měsíčků, výroba pobytových znamení, kontakt se zvířaty a péče o ně), tedy aktivity, které zároveň lektoři a učitelé hodnotili jako nejpř́nosnější pro proces inkluze (část žáků ale tyto činnosti nebavily), a dále herní aktivity (např. hra na lumky). Někteří žáci pozitivně hodnotili i samotnou možnost být v př́rodě. Zde však bylo hodnocení nejednotné (viz níže).

$\checkmark$ rámci evaluace byl zaznamenán odstup některých žáků $z$ běžné základní školy a většího počtu žáků z praktické školy od přírodního prostředí (ostych z živočichů, nezájem o pobyt v prírodě). Kontroverzně bylo vnímáno zimní venkovní setkání - část učitelek a žáků jej hodnotila pozitivně, část negativně (roli pravděpodobně hrálo počasí a vybavenost žáků do náročnějších podmínek).

\section{Zjištění podrobně - osobnostně sociální linie:}

Osobnostně sociální linie zahrnovala jednak aktivity výhradně zaměřené na osobnostně sociální rozvoj (sebepoznávání, sebekontrola, rozvoj spolupráce s druhou skupinou apod.), ale zároveň prolínala i do dalších dvou linií (rozdělování dětí do skupin, vzájemná spolupráce apod.). Aktivity z osobnostně sociální linie se ukázaly důležité při úvodním setkání a prvním seznamování se obou skupin (ledolamky). Některé reakce učitelů a žáků ale ukazovaly na to, že vzájemné propojování obou tříd prostřednictvím aktivit této linie nebylo spontánní a některým žákům bylo až nepř́ijemné (zejména blízký fyzický kontakt $s$ druhou tř́́dou). Pro projekt jako celek hrála významnou roli práce s pravidly, které umožňovaly udržovat žáky $v$ potřebných hranicích $v$ rámci programu a které zároveň ukazovaly i na samotný význam pravidel v lidské činnosti. Na základě vyjádření lektora odpovědného za tuto linii by práce s pravidly ale potřebovala určité drobné přehodnocení.

Dle vyjádření učitelek měly některé aktivity této linie a práce s pravidly nemalý význam i pro fungování kolektivu tříd základní školy (stmelení třídního kolektivu, převzetí některých pravidel).

Z osobnostně sociálních aktivit si žáci nejvíce vybavovali aktivitu s padákem, hru $\mathrm{s}$ řazením na provaze a aktivitu, při které se připravovali o "ocásky“. Mimo to se objevily 
aktivity z pobytu (housenka a evoluce), což mohlo být ale ovlivněno tím, že tyto aktivity bezprostředně předcházely rozhovoru $\mathrm{s}$ dětmi. Někteří žáci jako zajímavé zmiňovali postupné vytváření mapy a líbila se jim také tajemná truhla a činnosti spojené s ní.

Úvod do aktivit a jejich reflexe byly ale opakovaně přiliš dlouhé ve srovnání s vlastní realizací aktivity. Tento problém se objevoval i při práci s pravidly (místy př́liš dlouhé instruování ze strany lektora). Pro mladší žáky (tým C) a žáky z praktických škol byly některé aktivity př́liš náročné z hlediska jejich dovedností, přirozené schopnosti spolupráce a trpělivosti (např. přenos bomby $v$ kolečku na provázcích). $U$ těchto náročnějších aktivit se pravděpodobně zvýrazňoval rozdíl mezi žáky běžných a praktických škol, což mohlo zvyšovat napětí mezi oběma skupinami.

\section{Zjištění podrobně - forma tvořivě vzdělávacího cyklu:}

Zvolenou formou programu rozumíme to, že program byl nastaven na celý školní rok, jednotlivá většinou jednodenní setkání probíhala $v$ trítýdenních až měsičních intervalech, součástí bylo i dvoudenní pobytové setkání.

Lektorům i většině učitelů se zdála tato forma být ideální. Uskutečněná setkání mohli bezprostředně využít pro další výuku a v poločase se mohli začít připravovat a těšit na další setkání. Pouze učitelky v týmu A by uvítaly kratší interval mezi jednotlivými setkáními (cca po čtrnácti dnech). To se ale neosvědčilo ve vývojovém cyklu - učitelky hodnotily taková setkávání jako př́liš častá s tím, že nestíhají další povinnosti ve výuce.

Evaluace ukázala, že použitá forma směřovala k inkluzi, ale nemohla ji zajistit v plném rozsahu, a to díky samotnému nastavení i díky dalším faktorům, které měly vliv na průběh spolupráce. Jako určité řešení se nabízí možnost, aby ve spolupráci pokračovali samotní učitelé již mimo projekt.

\section{Zjištění podrobně - motivační linka programu:}

Evaluace ukázala, že ne zcela fungovala motivační linka "dva jsou víc než jeden". Lektorům se podařilo díky úvodním osobnostně sociálním aktivitám i díky motivační lince programu vzbudit $v$ žácích zvědavost a zájem o druhou skupinu ve smyslu: kdo budou ti druzí; co budeme mít společného; když do toho půjdeme spolu, více toho dokážeme. To také bylo cílem lektorů. Žáci běžné ZŠ v týmu $B$ tento záměr realizátorů v průběhu programu zaznamenali a zmínili ho i v rámci evaluačního rozhovoru. $Z$ průběhu programu se však ukázalo ( $a$ bylo to patrné právě $v$ týmu $B$ ), že žáci běžné základní školy (i přes počáteční snahu pomáhat žákům praktické školy) ztráceli trpělivost při opakovaném vysvětlování pravidel, opakovaném zadávání úkolů, rozdělování do skupin, pomalém čtení dětí z praktické školy apod., nadanější žáci běžné základní školy nedokázali porozumět myšlení a chování žáků z praktické ZŠ. A zřejmě tady někde se střetla poměrně vysoká motivovanost dětí z běžné ZŠ s limity vlastní skupiny i skupiny praktické ZŠ. Místo aby se společně vrhli do úkolů, které před nimi stály a které se lépe zvládají ve dvou, tř́́da běžné ZŠ za sebou „táhla“ tř́du praktické ZŠ, což zřejmě vyústilo $\mathrm{k}$ výraznému snížení zájmu o spolupráci s dětmi $z$ praktické školy.

\section{Celkové závěry/diskuze}

Evaluace přinesla odpovědi na to, jak fungoval proces inkluze $v$ rámci programu. Zároveň přinesla významné podněty k podobě programu - struktuře, časovému rozložení jednotlivých setkání, obsahu, personálnímu zabezpečení i motivaci. Z výsledků evaluace 
nelze jednoznačně vyvozovat obecné závěry a pravdy, protože předmětem evaluace byly jednotlivé př́padové studie, nejednalo se o plošný výzkum. Přesto jsou výsledky inspirativní např. $v$ tom, jakým směrem je možné se $v$ rámci inkluze vydat, na co klást důraz, jak postupovat, čemu se vyhnout a co ošetřit. Vždy je ale třeba zvažovat a vyhodnocovat aktuální podmínky, v kterých má proces inkluze probíhat.

\subsection{Proces inkluze v programu}

Evaluace vývojového i tvořivě vzdělávacího cyklu ukázala, že program „Dva jsou víc než jeden" může přinést výsledky $\vee$ rozvoji vztahů $v$ jednotlivých zapojených tř́iách a do určité míry i v navazování kontaktů, vzájemném poznávání a v rozvoji spolupráce napříč tř́́dami (program např. podporoval individuální kamarádství, ochotu pomoci). Evaluace zároveň ukázala, že proces inkluze probíhal v každém zapojeném týmu trochu jinak - na to měly vliv zejména různé vstupní faktory, ale i celkové nastavení programu, oboje je podrobněji popsáno níže.

V obou bězích vývojového cyklu spolu děti vzájemně dokázaly spolupracovat. $\checkmark$ řemesIné linii sice zůstaly tř́́dy po celou dobu realizace projektu spíše oddělené, ale děti byly ochotné si vzájemně pomoci. Naopak specifikem skupiny $v$ environmentální linii bylo to, že se děti z významné části mezi sebou znaly (některé spolu i dřive chodily do tř́dy), takže nebyl takový problém s navázáním kontaktů při programu.

$\checkmark$ rámci tvořivě vzdělávacího cyklu proběhlo sblížení obou tříd nejvíce ze všech tří týmů v týmu $A$, na úrovni jednotlivců pravděpodobně vznikla nová kamarádství, navázané vztahy mezi některými žáky obou tř́d přetrvaly i bezprostředně po skončení programu. $V$ rámci týmu $B$ se nepodařilo ve větší míre zajistit propojení obou tříd. $V$ týmu $C$ se podařilo částečně odbourat počáteční nejistotu $\mathrm{z}$ „jinakosti" žáků praktické školy v očích žáků základní školy, $\mathrm{k}$ významnému sblížení dětí napříč třídami došlo jen v několika jednotlivých případech.

Kvantitativní část evaluace tvořivě vzdělávacího cyklu (dotazníkové šetření) ukazuje, že zájem o spolupráci s druhou třídou se $v$ týmu $A$ a v týmu $C$ po absolvování programu nezvýšil, ale tento výsledek může být vnímán jako pozitivní, pokud ho budeme interpretovat tak, že žáci deklarovali zájem o spolupráci již na začátku programu. $\mathrm{K}$ tomu je třeba uvést, že zadávání dotazníků na začátku programu probíhalo až po dvou oddělených a prvním společném setkání, která byla zaměřena na motivování žáků pro setkání s druhou třídou, a evaluace tak ukázala, že tato motivace byla účinná. Proto další přímá zkušenost již nemusela tento zájem více pozitivně ovlivnit, ale jen ho potvrdila. Druhou interpretací je sociální desirabilita, kdy je možné, že žáci při vyplňování testu neodpovídali podle svého skutečného přesvědčení a do určité míry se stylizovali směrem k očekávaným "správným" odpovědím. Této interpretaci odpovídala některá kvalitativní data, ale jen velmi omezeně. Možných interpretací je ale více, a to i vzhledem $\mathrm{k}$ výsledku v týmu $\mathrm{B}$, kde zájem o spolupráci v prípadě běžné základní školy výrazně poklesl. Vysvětlením mohou být specifika jednotlivých skupin, které se $v$ rámci projektu setkaly, ale určitá komplikace mohla být i v nastavení programu. Kvalitativní data ukázala, že celkové výsledky odrážejí oba tyto faktory - viz níže charakteristika skupiny a motivační linka programu.

Co se týče hodnocení inkluze lektory, jejich očekávání v oblasti inkluze byla spíše střízlivější, zejména $v$ rámci později realizovaného tvořivě vzdělávacího cyklu (na základě předchozích zkušeností), u učitelek byla očekávání o něco výraznější - obecně se domnívaly, že spojení tříd bude snazší, že bude fungovat lépe, než ve skutečnosti (a to napříč jednotlivými týmy). 


\subsection{Vstupní faktory ovlivňující proces inkluze}

Velkou roli v realizaci projektu/programu hrály vstupní faktory. Evaluace ukázala, že do obdobných aktivit by se měly zapojovat/vybírat školy, které projevují zájem nejen o tematické zaměření programů, ale reálně mají zájem i o problematiku inkluze. Pokud učitelé alespoň částečně projevovali zájem o problematiku inkluze, i jejich žáci byli více motivovaní k vzájemné spolupráci a poznávání se. Zároveň se ukázalo, že je velmi důležité ujasnit si s učiteli konkrétní očekávání od programu i možnosti realizátora programu očekávání naplnit, což opět napomohlo hladkému průběhu zejména tvořivě vzdělávacího cyklu. Do vstupních faktorů, které velmi ovlivnily realizaci programu, jednoznačně spadá charakteristika skupiny. Evaluace ukázala, že je třeba individuálně zvažovat, jaké třídy spojovat. Spojení a spolupráce lépe fungovaly v rámci tříd běžné a praktické ZŠ, které byly z jednoho místa (jednak z toho důvodu, že se žáci mezi sebou znali, jednak z toho důvodu, že na započatou spolupráci mohli učitelé dále navázat). Dále se zdá, že lépe se pracuje se tř́ídami, mezi kterými nejsou tak výrazné rozdíly v oblasti schopností dětí. Speciální pozornost je třeba věnovat žákům, kteří výrazně vybočují svým chováním, emocionálními projevy, dovednostmi, př́p. i vzhledem, a to nejen v průběhu programu, ale již při př́pravě - je třeba řešit s učitelem, jakým způsobem se daný žák projevuje a za jakých okolností jaké metody práce Ize využít, jak moc být ve vztahu k danému žákovi přísný, zda je potřebná pomoc asistenta apod. Případné konflikty totiž vznikaly nejvíce právě v důsledku osobnostních specifik jednotlivců. Evaluace také ukázala, že je třeba pracovat s ,jinakostí“ dětí (ve smyslu jiné barvy pleti, vlasů), zejména tam, kde se žáci s takovou „jinakostí" ještě nesetkali.

\subsection{Nastavení a realizace projektu/ programu}

Významnou roli hrálo také celkové nastavení a realizace programu. Evaluace ukázala, že je třeba zabývat se otázkou motivace žáků k účasti na programu, zejména otázkou motivace žáků běžné ZŠ pro setkávání s žáky praktické ZŠ. Pro hlavní linku (směřování/motivaci) programu by byla asi vhodnější jiná motivace, než jaká byla v programu nastavena. Nikoli ve smyslu „dva jsou víc než jeden”, která do určité míry narážela, ale spíše nějaká méně kontroverzní myšlenka, např. „dva z jednoho města”, "dva z jedné lodi“ apod. - ve smyslu, že jsme jiní, ale z jednoho místa a společně si tu tvoříme prostor pro život, proto bychom o sobě měli navzájem vědět, lépe se poznat, něco spolu zažít a zkusit se naučit respektovat a do určité míry spolupracovat.

Učitelé zapojení do vývojového i tvořivě vzdělávacího cyklu velmi oceňovali velkou propracovanost programu. Zejména pak dle vyjádření učitelek byl tvořivě vzdělávací cyklus detailně a systematicky zpracovaný, a vedený s potřebnou odbornou erudicí i zájmem. Atraktivita programu byla tak vysoká, že předčila očekávání učitelek. Z vyhodnocení jednotlivých typů aktivit, resp. linií - osobnostně sociální, environmentální, řemeslné - ve vztahu k inkluzi vyplývá následující:

Osobnostně sociální linie nabídla aktivity a přístupy, které by bylo vhodné zachovat - zejména stmelovací aktivity a aktivity jednodušší povahy, ale zároveň na základě evaluace vyžaduje určité úpravy - ty se týkají práce s pravidly, práce se zadáváním a vyhodnocováním aktivit (délka a míra reflexí); změny by se měly týkat též aktivit, které vyžadují vyšší míru strategického uvažování, a také je třeba přehodnotit aktivity ve vztahu k věku žáků. Evaluace ukázala, že výběr osobnostně sociálních aktivit je vhodné odvozovat i od některých specifických/problematických situací, které mohou v průběhu programu nastat - např. nechut' k fyzickému kontaktu, překvapení z „jinakosti" (např. první bližší setkání s romskými dětmi), zapojování některých problematických dětí apod. Osobnostně sociální linie měla vliv na zlepšení fungování kolektivu některých tříd. Pro chování dětí v jednotlivých třídách měla 
velký význam práce s pravidly, ty si třídy převzaly i do svého utváření vztahů po skončení programu. Spojování tříd pomocí některých osobnostně sociálních aktivit ale připadalo některým učitelům a žákům jako nepřirozené a některým žákům bylo nepříjemné.

Největší potenciál pro inkluzi měla řemesIná linie - řemesIné aktivity, při kterých se nejvíce stíraly rozdíly mezi jednotlivými tř́dami (třídou běžné ZŠ a třídou praktické ZŠ). ŘemesIná linie (a dá se očekávat, že toto ž̌ejmě platí i pro další linie) by měla zahrnovat aktivity, s kterými se žáci běžně nesetkávají ve výuce, jsou pro ně nové (to vyplynulo $z$ evaluace vývojového cyklu). Na základě výsledků evaluace tvořivě vzdělávacího cyklu se ukázalo, že aktivity zvolené $v$ rámci řemesIné linie splnily očekávání nejen lektorky odpovědné za tuto linii, ale dokonce předčily očekávání učitelů; byly atraktivní a podporovaly inkluzi ve vztahu $\mathrm{k}$ žákům. Mj. ukázaly možnosti pracovního uplatnění žákům praktické školy.

Environmentální linie také nabídla aktivity a prístupy, které by bylo vhodné zachovat - zejména činnosti spojené s prací (práce $v$ lese, sázení měsíčků, výroba pobytových znamení, kontakt se zviřaty a péče o ně); zároveň i tato linie, jak vyplývá z evaluace, vyžaduje určité změny a úpravy - ty se týkají zejména aktivit, které vyžadují vyšší míru strategického uvažování (podobně jako u aktivit osobnostně sociálních). Náročnější aktivity byly spojené se ztrátou pozornosti či upozaděním žáků praktické školy. Vhodné by bylo zvážit aktivity i s ohledem na vybavení žáků k pobytu v př́rodě.

Celkově výsledky evaluace ukázaly, že lépe fungovaly aktivity, kde se stíraly rozdíly mezi dětmi (zejména řemesIná linie).

Výborně hodnoceno bylo personální zabezpečení projektu/programu - vysoká odborná a pedagogická úroveň lektorů, kteří byli schopni pracovat s náročnější skupinou dětí a kteří si dokázali poradit i s obtížnými situacemi. K dětem přistupovali partnersky a rovnocenně. Nezanedbatelným aspektem byla i př́tomnost lektorů - mužů jako vzorů, zejména pro chlapce nejen z praktických škol.

Forma zvolená pro vývojový cyklus byla časově hodně napjatá (setkání ve čtrnáctidenních intervalech), což bylo do značné míry dáno harmonogramem projektu. Učitelé by uvítali rozprostření jednotlivých setkání rovnoměrně ve školním roce. Forma zvolená pro tvořivě vzdělávací cyklus se osvědčila - program byl nastaven na celý školní rok, jednotlivá většinou jednodenní setkání probíhala $v$ třítýdenních až měsíčních intervalech, součástí bylo i dvoudenní pobytové setkání. Lektorům i většině učitelů se zdála tato forma jako ideální. Každé uskutečněné setkání mohli bezprostředně využít pro další výuku a v poločase se mohli začít připravovat a těšit na další setkání. Pouze učitelky v týmu A by uvítaly kratší interval mezi jednotlivými setkáními (cca po čtrnácti dnech). Toto se ale neosvědčilo ve vývojovém cyklu - učitelky hodnotily taková setkávání jako přiliš častá s tím, že nestíhají další povinnosti ve výuce. Evaluace ukázala, že použitá forma směřuje k inkluzi, ale nemůže ji zajistit $v$ plném rozsahu, a to $z$ důvodu samotného nastavení (nešlo o každodenní fungování, ale jen o nárazové a ještě časově omezené). Jako určité řešení se nabízí možnost, aby ve spolupráci pokračovali samotní učitelé již mimo projekt.

\section{Použitý design evaluace}

Pro evaluaci vývojového cyklu byl zvolen kvalitativní přístup, pro evaluaci tvořivě vzdělávacího cyklu pak smíšený design evaluace. Oba př́stupy umožnily shromáždit velký objem dat, která po analýze přinesla odpovědi na evaluační otázky. Smíšený design vedl ke konfrontaci kvantitativních dat s kvalitativními, což umožnilo spolehlivější interpretaci. Určitě vhodné bylo získat data od všech zainteresovaných skupin - od žáků, učitelů i lektorů - čímž byly získány i různé úhly pohledu. 
Žádoucí změny či posuny $v$ nastavení evaluace by mohly zahrnovat posílení sběru dat od žáků $v$ rámci vývojového cyklu a doplnění této informace o data $z$ ohniskové skupiny. $\checkmark$ prrípadě tvořivě vzdělávacího cyklu by také mohl být posílen sběr dat od žáků a prípadně $i$ učitelů a lektorů, a to ve smyslu časovém. Vzhledem $\mathrm{k}$ tomu, že tento cyklus probíhal po dobu téměř celého školního roku, bylo by vhodné provést sběr dat na začátku programu a pak i na konci programu. Na některé dotazované aspekty si nejen žáci, ale i ostatní zainteresované skupiny hưře vzpomínali, př́padně tyto vzpomínky byly překryty aktuálními dojmy a zážitky.

\section{Shrnutí}

Článek přináší výsledky evaluace vzdělávací části projektu "Dva jsou víc než jeden" realizovaného po dobu dvou let organizací Čmelák - Společnost přátel př́rody. Projekt byl zaměřen zejména na ověřování metod přispívajících k inkluzi ve vzdělávání. Projekt nabídl určitý alternativní prístup $\mathrm{k}$ této otázce.

Hlavní cíl projektu byl naplněn vytvořením proinkluzivních žákovských týmů (vždy jedna třída běžné základní školy a jedna třída praktické základní školy), které absolvovaly bud' kratší cyklus společných setkání (vývojový cyklus), nebo delší cyklus společných setkání (tvořivě vzdělávací cyklus). Hlavním předmětem setkávání a zároveň hlavními prostředky inkluze byly osobnostně sociální, řemesIné a environmentální aktivity.

Evaluace byla zaměřena především na sledování procesu inkluze - na vyhodnocení průběhu spolupráce mezi žáky tříd běžné a praktické základní školy, dále na vyhodnocení osobnostně sociálních aktivit, environmentálních aktivit a řemesIných činností jako prostředku inkluze, a také na vyhodnocení formy, která byla pro realizaci programu zvolena. Evaluace využívala zejména kvalitativní přístup, kde hlavními zdroji dat bylo pozorování a rozhovory $\mathrm{s}$ učiteli, lektory, př́p. i žáky. $\mathrm{V}$ rámci tvořivě vzdělávacího cyklu byl součástí evaluace i kvantitativní př́stup, v němž bylo zahrnuto dotazníkové šetření mezi žáky.

Proces inkluze probíhal v každém zapojeném týmu odlišně. $V$ rámci vývojového cyklu - v řemesIné linii - zůstaly tř́dy po celou dobu realizace projektu spiše oddělené, ale děti byly ochotné si vzájemně pomoci. $V$ environmentální linii se děti z významné části mezi sebou znaly, takže neměly problém s navázáním kontaktů. Konflikty vznikaly spíše na základě osobnostních specifik jednotlivců. $V$ rámci tvořivě vzdělávacího cyklu došlo $v$ týmu A ke sbližení obou tříd nejvíce ze všech týmů, na úrovni jednotlivců pravděpodobně vznikla nová kamarádství, navázané vztahy mezi některými žáky obou tříd přetrvaly i bezprostředně po skončení programu. Program měl $v$ tomto týmu pozitivní vliv na změnu v komunikaci mezi žáky běžné základní školy a jejich ochotu pomáhat druhým. Žáci praktické školy získali srovnání $s$ dětmi $z$ běžné školy a mohli si o nich vytvořit lepší představu a mínění. $V$ týmu $B$ se nepodařilo ve větší míre zajistit propojení obou tříd. $V$ průběhu programu došlo u žáků běžné základní školy k relativně značnému snižení zájmu o vzájemnou spolupráci s tř́ídou praktické školy. Program ale měl pozitivní vliv na větší propojení dětí uvnitř třídy běžné základní školy (nadané $s$ méně nadanými dětmi). $V$ týmu $C$ se podařilo částečně odbourat počáteční nejistotu $z$ „jinakosti" žáků praktické školy $v$ očích žáků základní školy. $\mathrm{K}$ významnému sblížení dětí napříč třídami došlo jen v několika jednotlivých případech. Žák běžné školy, který obtížně navazoval vztahy ve své třídě, dokázal navázat vztahy s žáky praktické školy. Pravidla uplatňovaná $v$ projektu měla pozitivní vliv na utváření vztahů ve tř́ídě běžné Zš i mimo program.

Evaluace ukázala, že osobnostně sociální, řemesIné i environmentální aktivity mají potenciál $k$ využití v inkluzivním vzdělávání - mohou být prostředkem inkluze. Pro potřeby 
inkluze se osvědčily jako jednoznačně nejvhodnější řemesIné aktivity. Dále se $z$ hlediska inkluze ukázaly jako vhodné i aktivity osobnostně sociální a environmentální - zejména ty, které měly motivovat žáky obou typů škol k vzájemnému setkávání, a dále ty, které byly založené na hře a pracovní činnosti. Evaluace také odhalila některé problematické aspekty programu - např. ve zvolené základní motivaci žáků ke kontaktu s druhou třídou. Dále pomohla odhalit několik kritických faktorů, na které je třeba vždy dopředu myslet a řešit je ještě před realizací programu - patří sem zejména složení/charakteristika skupiny, očekávání učitelů a jejich postoje $\mathrm{k}$ inkluzi, případně další organizační zajištění; tyto faktory mohou výrazným způsobem ovlivnit realizaci programu.

Věŕíme, že prezentované výsledky evaluace alternativního inkluzivního programu i jeho metodika mohou přinést inspiraci pedagogům a dalším realizátorům inkluzivního vzdělávání např. $v$ tom, jak zahájit proces inkluze, pokud zatím nemají možnost realizovat inkluzi standardním způsobem ( $v$ plném rozsahu ve školním prostředí, příp. i s přesahem do místní komunity). Dále by mohly poskytnout inspiraci realizátorům environmentální výchovy a ukázat, jak by mohla být oblast jejich zájmu nejen cílem sama o sobě, ale také prostředkem pro dosahování jiných výchovně vzdělávacích cílů, $v$ tomto případě cílů v oblasti inkluze. Výsledky jsou také inspirací realizátorům $\mathrm{i}$ evaluátorům programů $\mathrm{v}$ tom, jak evaluovat dlouhodobé výchovně vzdělávací programy.

\section{Poděkování}

Na tomto místě děkujeme zástupcům organizace Čmeláka - Společnost přátel př́rody, všem organizátorům i lektorům, kteří se podíleli na realizaci projektu/programu "Dva jsou víc než jeden", a zároveň všem pedagogickým pracovníkům zapojených škol i jejich žákům za to, že svým vstřícným přístupem a spoluprací umožnili hladký průběh evaluace.

Děkujeme také za finanční podporu projektu "Dva jsou víc než jeden" včetně jeho evaluace $v$ rámci Operačního programu Vzdělávání pro konkurenceschopnost. Projekt byl financován z Evropského sociálního fondu a rozpočtu České republiky a je veden pod registračním číslem CZ.1.07/1.2.23/02.0016.

\section{Literatura}

- Bartoňová, M., \& Vítková, M. (Eds.). (2007). Přístupy ke vzdělávání žáků se specifickými poruchami učení na základní škole. Brno: Paido.

- Černá, M. (2012). Jak dál v inkluzivním vzdělávání? E - Informační bulletin pro organizace pưsobící v sociální a zdravotně sociální oblasti, 1-2. Retrieved from http://www.skok.biz/images/stories/e-IBSKOK-082012.pdf

- Greger, D., Chvála, M., Walterová, E., \& Černý, K. (2009). Názory českých rodičů a veřejnosti na časné rozdělování žáků. Orbis Scholae, 3(3), 51-78. Retrieved from http://www. orbisscholae.cz/2009/cislo-3

- Hájková, V., \& Strnadová, I. (2013). Denotace inkluzivního vzdělávání s odkazem pro vzdělávací praxi v České republice. Pedagogika, časopis pro vědy o vzdělávání a výchově, 62(2), 252-258. Retrieved from

http://pages.pedf.cuni.cz/pedagogika/? $p=542$

- Hájková, V., \& Strnadová, I. (2010). Inkluzivní vzdělávání. Praha: Grada. 
- Chráska, M. (2007). Metody pedagogického výzkumu. Praha: Grada.

- Lechta, V. (Ed.). (2010). Základy inkluzivní pedagogiky. Praha: Portál.

- Průcha, J., Walterová, E., \& Mareš, J. (2007). Pedagogický slovník (4th Ed.). Praha: Portál.

- Škvaříček, R., \& Šed’ová, K. (2007). Kvalitativní výzkum v pedagogických vědách. Praha: Portál.

- Titzl, B. (2009). Cílové skupiny současné speciální pedagogiky. In Rovné př́ležitosti $v$ edukaci osob se speciálními potřebami (pp 208-210). Ostrava: Ostravská univerzita.

Mgr. Lenka Broukalová, evaluátorka programů, Spora, o. s., broukalova@spora.cz Václav Broukal, evaluátor programů, Spora, o. s., broukal@spora.cz

PhDr. Jan Činčera, Ph.D., pedagogický pracovník, Technická univerzita Liberec, jan.cincera@tul.cz 